\title{
The Political Economy of New Zealand's Consumers Price Index
}

\author{
By
}

\section{Corin Higgs}

A Thesis submitted to the Victoria University of Wellington in fulfilment of the requirements for the Degree of Masters of Arts in Political Science

School of History, Philosophy, Political Science \& International Relations Victoria University of Wellington 


\section{ABSTRACT}

The structure of New Zealand's Consumers Price Index has changed many times over its 100 year history. As New Zealand's most influential and consequential official statistic the CPI performs political and distributional functions that affects 'who gets what and when'. Some observers suggest that change in the structure of the CPI is merely the consequence of technological improvement which in turn alters the conduct of policy-making and politics.

This study turns that assumption on its head by demonstrating that it is politics that has altered the technology known as the CPI. Through the examination and evaluation of the changing political and economic context that the index operates within, this thesis work finds that the CPI was transformed by the very political forces it was designed to contain.

This thesis argues that because the index functions as political decision-making tool that supports the setting of salaries and wages, benefit levels and interest rates, change in the form of the index is a result of struggle among interests affected by these highly political decisions.

This thesis makes its case through analysis of primary sources and official documentation relating to the development of the index. The first case study tracks the origins of the first official index in 1914, devised in order to learn what it cost a 'working' family to meet its basic needs through its transformation into a tool that set wages and measured price change in the wider economy. This is reinforced by a study of change to the index since the 1970s, focusing on the use of the CPI in the conduct of monetary policy that resulted in a politically driven change to the measurement of household inflation. These case studies are further supported by examination of the secondary literature on price indexes, monetary policy and institutional change theory.

This thesis adds to the body of knowledge on theories of institutional change by presenting evidence of the conflict that has caused political change to the technology of the CPI. 


\section{ACKNOWLEDGEMENTS}

I would like to gratefully acknowledge the support I have had from an assortment of people and organisations without which this thesis would not have been possible.

First and foremost, I must give my utmost thanks and appreciation to my primary supervisor Dr John Leslie. John has been of great support and encouragement throughout this long process, from its inception as a research proposal, to its development into this thesis.

Thanks is also due to my secondary supervisor Professor Sharleen Forbes. Your extensive understanding and insight into the mechanics of the CPI was invaluable in creating this work.

I must also thank my replacement supervisor Dr Ben Thirkell-White who stood in for John during his sabbatical and whose ability to tell the faculty what they needed to hear enabled me to complete this thesis whilst maintaining full-time employment.

Thanks also to Evan Roberts, who invited me to participate in the Summer Scholarship research programme that allowed me to study the history of the CPI at Statistics NZ many years ago. This unique experience inspired me to put together a research proposal that has eventuated in this thesis.

I wish to thank a group of peers and friends who without their support this thesis would not exist. Firstly Matthew Castle, even though he has departed for greener pastures in Canada, Matthew was essential in motivating me to submit a research proposal in the first place. Matt was an essential sounding board for the many ideas in this thesis, and is a role model for post-graduate study that is difficult to emulate.

Thanks also goes to my peers that entered the Master's thesis process at the same time including Ben Mclachlan, James Baigent, Jess Booker, Lucy Tyndall, Seonah Choi and Toni Grace. I was one of the first to enter and now I am the last to leave.

I am also grateful to a number of institutions, for without their generosity this research would not have been undertaken. I thank Victoria University of Wellington for granting me a scholarship and stipend as well a number of extensions to accommodate my later employment in Parliament. I also wish to thank Statistics NZ, in particular, Chris Pike and the Prices Unit for 
accommodating me over the summer of 2009/10 as part of the Summer scholarship programme. I also wish to thank the members of the Political Science \& International Relations Programme at Victoria University who have supported and encouraged me during my studies. I wish to specially thank Professor Stephen Levine, Dr Jon Johansson and Professor Nigel S. Roberts for their inspiration and support during my studies.

I would also like to thank the talented academics from whom I have learnt from during my study of the CPI including Brian Roper, Brian Easton, Chris Rudd, Nigel Haworth and Gary Hawke for their thoughtfulness regarding the study of price change in New Zealand.

I also thank my colleagues and my employer at the New Zealand Parliament for permitting time away from work following the recent election to complete this thesis.

Lastly I would like to thank my family, Cheryl, Peter, Byron, Billie and Kingsley. Thank you so much for constantly supporting me through this long process.

This thesis is dedicated to Louis. 


\section{Table of Contents}

$\begin{array}{ll}\text { Abstract } & 1 \\ \text { Acknowledgements } & 2\end{array}$

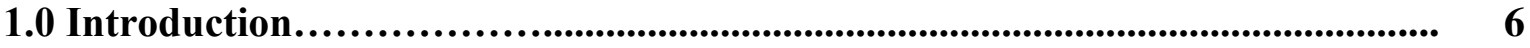

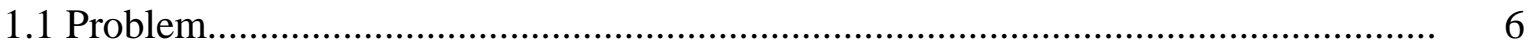

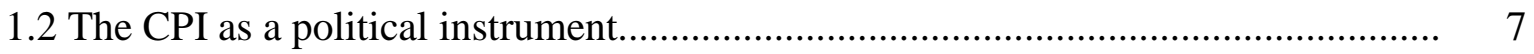

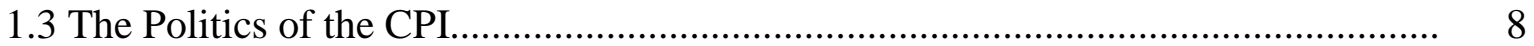

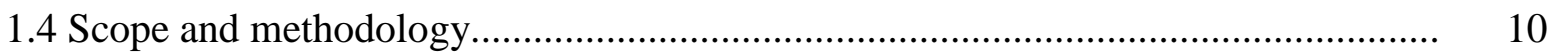

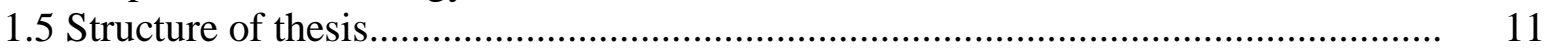

2.0 An overview of change in the CPI............................................... 14

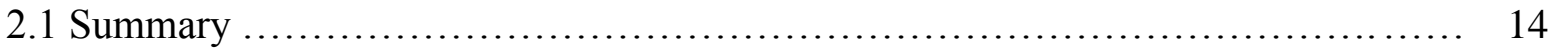

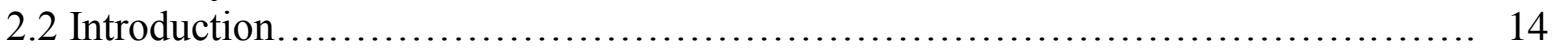

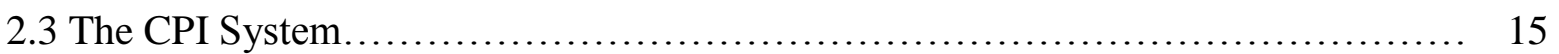

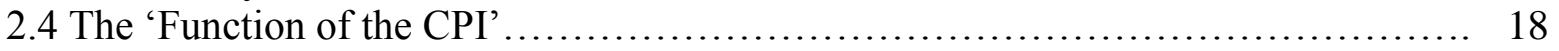

2.5 How the CPI works (Form) ................................................. 20

2.6 The conflict between form and function.................................... 21

2.7 Empirical Research Questions............................................. 23

2.8 Empirical Literature Review ................................................ 25

2.9 A Historical Institutionalist research approach.................................. 27

2.10 Review of literature regarding institutional change........................... 30

2.11 Theoretical Research Questions........................................ 34

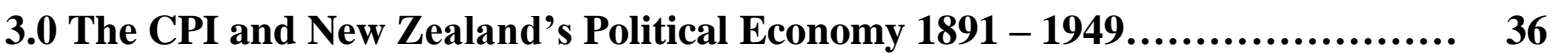

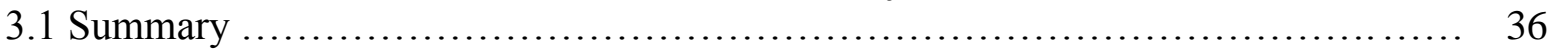

3.2 The 'Significant Change' ................................................... 36

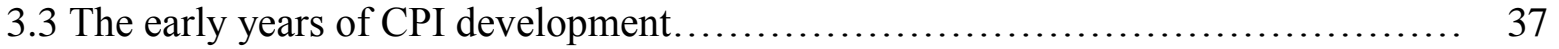

3.4 Assessing Social ills in 'Better Britain' ....................................... 37

3.5 The role of the Labour Department........................................... 38

3.6 The first price index........................................................... 40

3.7 Studying the 'Cost of Living'............................................ 41

3.8 The Royal Commission on the 'Cost of Living'................................. 42

3.9 The Government Statistician............................................... 44

3.10 The birth of the CPI.................................................... 46

3.11 The Court of Arbitration................................................ 50

3.12 The 1920 'Error': Politics changes the index.................................. 51

3.13 Changing international political influence.................................. 52

3.14 Depression, rejuvenation, politics and war ................................ 54

3.15 Creating an 'objective' CPI............................................... 56

3.16 How politics changed the index.............................................. 59

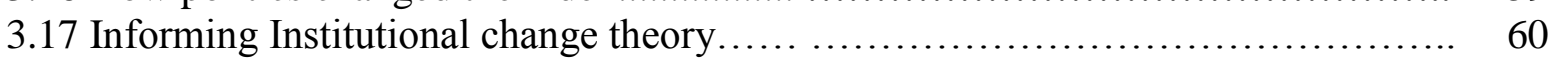


4.0 The CPI and the politics of Neo-Liberalism................................. 64

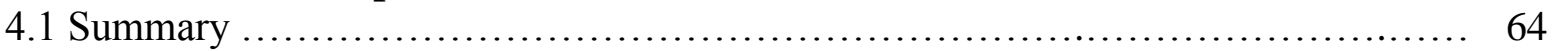

4.2 'Stagflation' and the rise of Neo-Liberalism.................................... 65

4.3 'Inflation Targeting' and the Reserve Bank Act................................. 66

4.4 The CPI and the 'Policy Target Agreement' .................................. 70

4.5 The 1997 CPI Revision Advisory Group ............................... 71

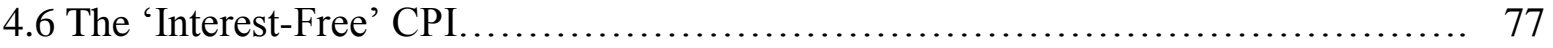

4.7 Informing Institutional Change theory.......................................... 79

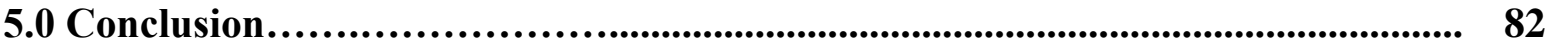

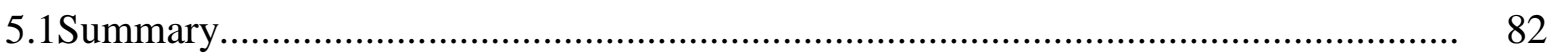

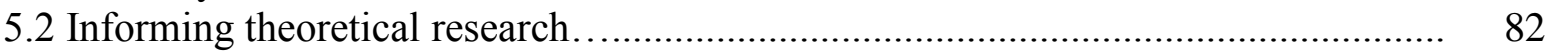

5.3 Areas for further empirical research on the CPI............................................ 83

5.4 Areas for further research regarding official statistics....................................... 84

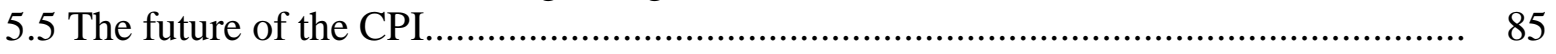

$\begin{array}{lr}\text { Bibliography } & 88\end{array}$ 


\section{CHAPTER 1 - INTRODUCTION}

\subsection{THE PROBLEM}

Many New Zealanders view the Consumers Price Index (CPI) as a politically neutral device that measures the relative change in price levels of goods and services. Most people regard the CPI as an 'objective' instrument, yet, by its very nature it is political. Once based on the subjective idea of the 'standard of living' of a 'working man', the index is now based on an 'objective' measure of aggregate household consumption. Items that had previously been excluded from the CPI 'basket of goods' such as alcohol and holiday travel, are included, yet despite its professed objectivity, interest and credit services are now excluded. From being a decision-making tool used by the Court of Arbitration in wage setting, the index has become a monetary policy 'target' of the Reserve Bank.

Inflation has been argued to be "the outcome of political conflicts". Different rates of price change affect the distribution of economic production to different groups and coalitions in society. But not only is the rate of inflation the outcome of political conflict, so too is the statistic commonly used to measure it in New Zealand - the Consumers Price Index.

The creation and evolution of the CPI is a profoundly political story. Over its 100 year history, the CPI has been linked to political, economic and social change in New Zealand. Accordingly, its design and usage are products of political struggle. What was first conceived as a tool of state interventionism in pursuit of the 'makeable society' at the beginning of the 20th Century has become, under the prevailing philosophy of market liberalism of the 21 st Century, an instrument to 'bind the hands of government'.

This study examines how the CPI was transformed by the political forces it was designed to contain. Classical liberals and Marxists view social and political development as a consequence of exogenous technological change. This research turns this assumption on its head by asking "Is technology political?", "Does technology shape politics or is technology shaped by politics?" and "If technology is influenced by politics, how?"

Official statistics are the cornerstone of contemporary governance. The Statistics Act states that official statistics are to be used by government, business and the public for the "purpose of making policy decisions, and to facilitate the

\footnotetext{
${ }^{1}$ Kirshner, Jonathan, 2001, 'The Political Economy of Low Inflation.' Journal of Economic Surveys 15(1), pp. 4170.
} 
appreciation of economic, social, demographic, and other matters of interest." ${ }^{2}$ Gross domestic product (GDP), the balance of payments and the CPI quantify economic phenomena that influence political decisions and outcomes. When deployed as 'objective facts' normative arguments can stem from these numbers, a decrease in GDP is 'bad' whereas a positive balance of payments is 'good'. Yet little attention is directed to the political epistemology of the numbers themselves. Rather than the 'objective facts' they are commonly accepted as, official statistics are coloured by the economy, society and politics they are the creations of.

\subsection{THE CPI AS A POLITICAL INSTRUMENT}

The CPI is New Zealand's most influential and consequential official statistic. The quantification of inflation measured by the CPI affects who gets what and when. This political institution measures the rate of price change in goods and services purchased by households. The quantification of price change represented by the CPI is responsible for the movement of billions of dollars annually both as a formal measure of inflation and an informal measure of the 'cost of living'. It was recently estimated that a 0.1 percentage point overestimate in the CPI would increase annual government expenditure by $\$ 16$ million. ${ }^{3}$ As a target for the setting of monetary policy, the level of the CPI is a determinant in the level of interest rates, which influences investment decisions. The CPI is linked to the level of exports, imports, employment and exchange rates. Yet despite the significant political consequence of the index most contemporary New Zealanders view the CPI as a politically neutral device. A recent survey of public trust in official statistics found that $80 \%$ of respondents felt that statistics published by Statistics New Zealand (New Zealand's official statistics agency) were either 'very free' or 'reasonably free' from political interference. ${ }^{4}$ The Statistics Act 1975 provides statutory independence to the Government Statistician, stating that this official "shall have the sole responsibility for deciding the procedures and methods employed in the provision of any statistics produced".

Yet the composition of the CPI is determined by a series of political, more so than rational or technological choices over time. Technically, there are many different ways to measure price change therefore the idea of one optimal choice to measure inflation is false. In addition, because New Zealand is one of few developed

\footnotetext{
${ }^{2}$ The Statistics Act 1975

${ }^{3}$ Office of the Minister of Statistics, 2011, 'Statistics 2020: Achieving the Statistical System of the Future'

Budget Cabinet Paper June 2011, http://www.treasury.govt.nz/downloads/pdfs/b11-2020979.pdf

${ }^{4}$ Research New Zealand, 2014, Use and Trust in Official Statistics Survey: 2013.

http://www.stats.govt.nz/ /media/Statistics/about-us/corporate-publications/use-trust-os-survey/use-trust-

os-survey-2013.pdf , p. 41
} 
countries to have a single 'catch-all' index that is used for multiple economic and political purposes, the structure of the index is a site of on-going political struggle. This thesis, however, is not an attack on the independence or professional integrity of the Government Statistician and Statistics New Zealand. Instead it will demonstrate that the belief that official statistics numbers are politically neutral is misguided because while "God made the integers, all else is the work of man."

\subsection{THE POLITICS OF THE CPI}

The CPI is a profoundly political institution, what today is seen as an 'objective' measure of price change is the cumulative outcome of historical and contemporary power-political relations. Change in the CPI has tended to occur incrementally through the exploitation of ambiguities in its conceptual basis and application of the statistic. The basis of the CPI was originally a prescriptive measure of the 'workingman's cost of living', which, over time became a positivist measure of price change in the purchases of a sample of all New Zealand households. In its first iteration, during the Great War, the CPI was used primarily in the adjustment of wages for the 'cost of living' by the Court of Arbitration. ${ }^{6}$ Today the foremost use of the CPI is as an 'inflation target' for the Governor of the Reserve Bank who is responsible for controlling the rate of price change. In essence, where the CPI was first developed a century ago to arbitrate the price of labour, it now adjudicates the price of capital. First conceived as a social tool of state interventionism in pursuit of the 'makeable society', the CPI is now, (in its monetary policy guise) an economic device of market liberalism used to 'bind the hands of government'.

The contemporary CPI measures price change in a representative sample of household purchases intended to reflect the present social and economic context. Generally, the scope of the statistic has expanded over time as the index has become more positivist and less prescriptive. Measurement of price change in alcoholic drinks and pornographic magazines, once excluded for moral and political reasons under the prescriptive approach, were added to the index in the decades following World War II. But in 1999 the long trend of expansion in the scope of the CPI was reversed when measurement of price change in interest rates was abandoned.

\footnotetext{
${ }^{5}$ Jeremy Gray (translation), 2008, Plato's Ghost: The Modernist Transformation of Mathematics, Princeton University Press, p. 153. Gray attributes the German quote to: "Weber 1891/92, 19, quoting from a lecture of Kronecker's of $1886 . "$

${ }^{6}$ The CPI was officially named the 'Retail Price Index' until 1949 when it became the Consumers' Price Index. The apostrophe was discarded in 1973. This study will use the term 'Consumers Price Index' to refer to the index irrespective of the time period.
} 
The justification for this change was that the inclusion of interest rates made the index too volatile for use by the Reserve Bank in monetary policy. As interest rates were raised in the hope of reducing inflation, the increased price of money would be reflected in the CPI (which included interest in its 'basket') which the Bank argued would create a 'feedback loop' where attempts to reduce inflation could cause higher inflation to be observed in the CPI.

On the other hand, representatives of workers and welfare recipients were strongly opposed to this change. Rather than seeing the CPI a tool to control inflation, they viewed the CPI primarily as a tool that allowed wage and welfare payments to keep pace with the 'cost of living' through indexation. From this perspective the removal of interest rates (which made up approximately 6.5\% of the CPI 'basket') distorted the CPI's quantification of the 'cost of living'. The political victory of the interests of certain groups and coalitions over others in the enactment of central bank 'independence' was not only reflected in politics of 'inflation targeting' it was mirrored in the construction of the CPI itself.

This particular episode highlighted the inherently political nature of the CPI. As a statistic with multiple disparate purposes, it is, as former Government Statistician Len Cook states, "impossible for any one index to meet the needs of all users". With multiple interests competing to influence 'who gets what, when, and how' from the outcomes of a statistic with such inherent ambiguity, the CPI cannot be anything but a political construction. The CPI, like other institutions, is embedded within a political context reflecting the cumulative preferences of historic and contemporary change agents. Therefore this study is primarily concerned with how and why institutions change over time.

\footnotetext{
7 Len Cook, 1989, "A Sample of Highlights in the History of Government Statistics." The New Zealand Statistician 24(2), pp. 57-65.
} 


\subsection{SCOPE AND METHODOLOGY}

This study will address the following questions:

i. Is change in New Zealand's CPI driven primarily by technological improvement or is it primarily driven by politics?

ii. Why did the basis of the CPI changed from a generally prescriptive measure of the 'cost of living' to a generally positivist measure of 'inflation'?

iii. Why did the removal of mortgage interest from the CPI regimen in 1999 occur?

iv. How has the process of change in the CPI occurred?

From a theoretical perspective, this thesis will also address the following questions:

i. Are these significant changes in the CPI examples of sudden or incremental change?

ii. Does 'path dependence' or 'layering and conversion' adequately explain the process of institutional change in the CPI?

The investigation of these questions entails the analysis of two specific episodes of change in the CPI:

1) The transformation of the prescriptive Retail Price Index into the positivist CPI that occurred over the first half of the $20^{\text {th }}$ century.

2) The removal of interest from the scope of the official CPI in the late 1990s.

A case study design is appropriate as it allows in-depth investigation of the processes and outcomes behind these specific episodes of change while drawing general inferences from these cases to a broader class of cases.

There are several reasons for the singular focus on New Zealand's CPI. The temporal and resource limitations imposed on a Master of Arts thesis and the paucity of existing research on New Zealand's CPI necessarily restrict the scope of this study. Presently the body of social science research into price indexes is minuscule even at the global level. Therefore one must choose between shallow comparative examinations of multiple national price indexes or a thorough evaluation of a single price index. Substantive research needs to be conducted on the price index systems of individual economies to allow informed comparative study to occur. Aside from a historical side-project of Statistics New Zealand to commemorate the recent centenary of the index, the body of existing social research on New Zealand's CPI is virtually non-existent. This thesis, therefore, offers a limited and by no means exhaustive historical examination of the 
development of the CPI underpinned by power-political relationships that alter institutions over time.

This thesis draws upon a combination of primary documentation and secondary literature. In analysing the development of the CPI, the thesis will examine the official documentation published by Statistics New Zealand and others that details the development and utilisation of the statistic. This thesis will also consult the secondary literature on the history and development of price indexes in the social science and economic fields. This study will also provide context through consulting the literature in regards to New Zealand's economic, social and political history.

\subsection{STRUCTURE OF THESIS}

This thesis will identify the causes and rationales of change in the CPI through examining historical power-political relationships and the exploitation of ambiguities in the basis and application of the statistic by dominant change agents.

The following chapter provides an overview of how the CPI has been constructed and utilised historically and contemporaneously. The chapter also examines ambiguities in the basis and purpose of the CPI as well as the relationship between change in the methodology of the CPI and it's utilisation in New Zealand society. Explanations for CPI change in literature on price indexes and statistics are evaluated as is the body of literature on institutional change.

Chapter three examines the process of change in the CPI from its genesis during the Great War as the prescriptive Retail Price Index to its post-WWII transformation into the 'positivist' CPI. The chapter identifies explanations for the development of the CPI within changing domestic and international powerpolitical relations that change interpretations of the conceptual basis of the statistic. The chapter concludes by evaluating how this story corresponds with existing theories on institutional change.

The fourth chapter examines the change in the CPI in the latter decades of the $20^{\text {th }}$ century with particular focus on the removal of mortgage interest from the scope of the CPI in the late 1990s. The chapter links this episode of technological change to the implementation of market liberal policies, deregulation and change in New Zealand politics and society that began in earnest following the 1984 election of the fourth Labour government. The chapter concludes by evaluating this case study within the context of institutional change theory and comparing this episode of CPI change with that outlined in chapter three. 
The concluding chapter of this thesis summarises these studies of CPI change and speculates on what the circumstances of change in the CPI means for other forms of constructed knowledge, in particular, developing statistical measures such happiness indicators and measures of climate change. Further areas of research in the field of institutional change and the social scientific study of price indexes and official statistics are identified. This thesis concludes by using these case studies to speculate on the future of the CPI within New Zealand's political economy. 


\section{CHAPTER 2 - AN OVERVIEW OF CHANGE IN THE CPI}

\subsection{SUMMARY}

This chapter examines the role of the CPI in contemporary and historical New Zealand society. It commences with an overview of the role of the CPI in contemporary New Zealand. A range of the historical changes to the calculation of the index are identified. This investigation is paired with an overview that examines the different ways the index has been utilised in New Zealand society. This will demonstrate the linkage between the political purposes that the CPI serves and the methodology of the index itself. The second section of the chapter evaluates explanations for CPI change in existing literature. Explanations in technical and economic studies of price indexes and related statistics will be identified. The limited range of works in the social sciences devoted to price indexes and statistics are evaluated followed by a brief overview of literature regarding New Zealand's social and economic history as it relates to the index. Turning from the empirical, theoretical explanations for institutional change are assessed with particular focus on the historical institutionalist school. The chapter concludes by outlining the scope, methodology and research questions used in the subsequent chapters.

\subsection{INTRODUCTION}

In 1948, a government appointed committee tasked with devising a revised 'costof-living index' recommended a series of statistical techniques and methods that transformed the 'Retail Price Index' into the 'Consumers' Price Index'. Unlike its predecessor, based on a 'workingman's cost of living', the remade statistic was based upon "the whole range of commodities and services used in the "average household" representing "the amenities of modern living". Almost half a century later, another government committee recommended, for the first time in history, a significant contraction in the scope of the CPI. To ensure greater 'accuracy' and lessen 'short-term volatility', household debt-service payments (such as mortgage interest) were removed from measurement in the official index.

These episodes of change to the CPI in the aftermath of WWII and the late 1990s share a commonality in that they were political, rather than 'scientific' decisions. These choices, which determined how New Zealand's national price index would be calculated, coincided with the prevailing domestic and international politicaleconomic consensus of the time. The post-WWII change to a positivist index

\footnotetext{
${ }^{8}$ Statistics Office. 1949, Monthly Abstract of Statistics, November 30 1949. Wellington: Government Printer.
} 
based on 'modern living' reflected the broad balance of 'embedded liberalism' struck between labour and capital under the Bretton Woods system. The transition to an 'interest-free' CPI in the late-1990s on the other hand was paired to the predominance of liberal market policies and the increased influence of the financial sector over government.

These changes were in part the result of the interaction of ideas, interests and institutions and exogenous factors. But these changes, while they may superficially appear to be so, were not sudden as the impetus for change was built up incrementally over time. But a shift in the balance of political power is not an adequate explanation of the reasons for CPI change. To overcome the historical legacy of the index in society, 'change actors' exploited ambiguities, misunderstandings and inconsistencies in the CPI system to bring about change.

To understand how these ambiguities and inconsistencies in the CPI system were used to bring about change, one must understand how the CPI is constructed and how it is utilised in New Zealand society.

\subsection{THE CPI SYSTEM}

A price index quantifies price change by measuring "the change in price between time periods for a given set of goods and services". " New Zealand's CPI is currently based upon the price change observed in a 'basket of goods' that represents domestic spending. Change measured in the value of the index over time is then utilised to make economic and political decisions regarding the distribution of resources.

Yet this simple definition portends a complex array of choices: Which goods and services are measured and which are not? Whose 'price change' is being measured and what is the 'representative consumer' of these goods and services? Is the value of every dollar spent treated equally (plutocratic) or are the spending patterns of each 'representative consumer' treated equally (democratic)? How is the CPI used to allocate resources? Furthermore why has the CPI been adopted as a distributive tool over other devices that may have equal or better technical merit? This dilemma is further exacerbated by the fact that the CPI serves multiple purposes of which it is not optimally suited.

\footnotetext{
${ }^{9}$ Statistics New Zealand, 2014, 'Consumers Price Index: June 2014 Quarter: Definitions', July 16 2014, http://www.stats.govt.nz/browse for stats/economic indicators/CPI inflation/ConsumersPricelndex HOTPJu n14qtr/Definitions.aspx
} 
Rather than viewing the index as a number alone, the political and economic importance of the CPI is as a 'system' that attempts to both mitigate the effects of, and control the rate of price change. This 'system' comprises a 'form' (the CPI itself) and 'function' (what is done with the statistic). ${ }^{10}$ Much of the political tension in the index stems from the competing objectives between and within the form and function of the CPI system.

Officially, the CPI is a metric of 'household inflation' that measures "the changing price of a fixed basket of goods and services" representing "the overall expenditure pattern of New Zealand households."11 But, despite not officially being so since at least the late 1940s, the CPI also serves as an informal measure of the 'cost of living'.

Although often seen as synonymous, 'inflation' and the 'cost of living' are distinct and separate economic phenomena. The 'cost of living' is generally defined as the rate of change in the amount of resources required to maintain a fixed amount of satisfaction over a period over time. On the other hand 'inflation' in the New Zealand CPI is the rate of price change in an aggregate cross-section of goods and services purchased by New Zealand households. Essentially 'inflation' measures the 'cost of things' rather than the 'cost of living'. Therefore the CPI as a measure of inflation includes items such as luxury goods that would not normally be considered as part of the 'cost of living' while a cost of living index may exclude items with high levels of consumption such as alcohol. As the index is based on aggregate consumption, the purchasing patterns of higher income households have greater influence on the contemporary CPI than lower income households.

The two overlapping but distinct forms of measuring price change are reflected in the two broad functions the index performs. As a 'compensation index' the index is used for 'cost of living' adjustments for many government transfer payments and income thresholds for state assistance. As a 'compensation index' the CPI is an informative tool for employees, employers and businesses seeking to adjust wages, prices or profit to compensate for price change. As an 'inflation index' the principal use of the CPI is to measure 'price stability' which is maintained through the monetary policy controlled by New Zealand's Reserve Bank. In essence, the CPI as a 'compensation index' mitigates the effects of price change while the CPI

\footnotetext{
${ }^{10}$ The terms 'form' and 'function' are taken from H. Spencer Banzaf, 'The Form and Function of Price Indexes: A Historical Accounting', History of Political Economy 36:4 2004

${ }^{11}$ Statistics New Zealand, 2014, 'Consumers Price Index: June 2014 Quarter: Definitions', July 16 2014, http://www.stats.govt.nz/browse for stats/economic indicators/CPI inflation/ConsumersPricelndex HOTPJu n14qtr/Definitions.aspx
} 
as an 'inflation index' is used to identify and assist in the control of the underlying causes of price change.

The method of calculating the CPI has considerable consequences in determining the outcomes it produces. To ensure broad public acceptance of the integrity of the statistic, the Government Statistician (head of Statistics New Zealand and a non-political appointee of the State Services Commission) has the sole legal responsibility "for deciding the procedures and methods employed in the provision of any statistics produced or to be produced by the Statistician, and shall also have the sole responsibility for deciding the extent, form, and timing of publication of those statistics." ${ }^{\prime 2}$ Yet the legislative protection extended to the CPI does not preclude politics from influencing the form of the statistic.

A fundamental principle of most national statistical offices is that the numbers they produce must be 'fit-for-purpose'. The Inter-Secretariat Working Group on Price Statistics (IWGPS), the international body that co-ordinates international practices of price index composition, recommends that Government Statisticians regularly consult with users of their statistics to ensure the numbers are meeting their needs and requirements. New Zealand is no exception to this practice, but unlike many other developed countries with multiple indexes performing multiple functions, the New Zealand CPI essentially has one form that performs multiple functions, which means compromises must be made. These compromises balance between the historical institutional characteristics of the CPI, the preferences of the dominant change agents and the contemporary political context.

Over the history of the index, such compromises have tended to favour the most politically powerful users of the index. For much of the first 50 years of the index's existence, the most prominent user of the CPI was the Court of Arbitration which used the index as a guide for the 'cost of living' in the determining wages for most New Zealand workers. In the past two decades the Reserve Bank has been the most politically significant user of the CPI, which is used to evaluate the monetary policy 'target' of 'price stability' for the Bank.

In the 1920s the scope of the CPI was vastly broadened because of the Court of Arbitration's wage determination requirements. In the 1990s it was the needs of the Reserve Bank that prompted the removal of mortgage interest rates from the CPI. Despite the form of the CPI being legislatively separate from the functions that it performs; political change in the way the index is used, can and does change the form of the statistic itself.

\footnotetext{
${ }^{12}$ The Statistics Act 1975
} 
But change in the form of the index can also occur without any corresponding change in the redistributive functions of the statistic. A CPI designed within approved international standards permits cross-border comparisons of price change, increasing certainty reducing the transaction costs of international trade. A primary factor in the initial creation of the index in the 1910s was the desire for Imperial comparability of prices across the British Empire. There is an argument that the post-WWII conceptual changes to the CPI, can to a degree, be linked to international rather than domestic causes. Although the removal of interest from the index in the 1990s has definite links to the imposition of market liberal policies such as central bank 'independence'; this change was also co-ordinated with Australian institutions, suggesting that the politics of regionalism may be just as salient as domestic politics in bringing about change to the form of the index.

\subsection{THE 'FUNCTION’ OF THE CPI}

The CPI as a measure of inflation serves as an essential indicator in the 'dashboard' of modern government. The contemporary approach to governance in New Zealand views the nation-state as a 'machine' to be tuned, aligned and calibrated according to the perceived conditions. Under the prevailing monetary policy framework of 'inflation targeting', the CPI can function as a speedometer for the pace of economic growth indicating whether the economy is 'overheating' and needs to be 'slowed down' (or 'sped up') by those with their hand on the lever.

As an indexation tool, the CPI is a compensation mechanism that attempts to 'smooth over' economic distribution between the 'winners and losers' as a result of price change over time. This use of the CPI is used to enable payments and receipts to 'keep pace' with the value of money. Payments such as social welfare benefits, student allowances, superannuation are adjusted yearly based on the rate of the CPI while some indirect taxes, such as excise taxes on alcohol, petrol and tobacco products are adjusted by the CPI annually. In the private sector, clauses invoking adjustments for the CPI often appear in long-term employment or investment agreements and contracts. 
TABLE 1: GOVERNMENT PAYMENTS AND RECEIPTS LINKED TO THE CONSUMERS PRICE INDEX

\begin{tabular}{|c|c|c|}
\hline & CPI index utilised & Effective from \\
\hline \multicolumn{3}{|l|}{ Revenue } \\
\hline Alcoholic beverages excise duty & CPI All Groups less Credit Services & \begin{tabular}{|l|l|}
1 July each \\
year
\end{tabular} \\
\hline Tobacco products excise duty & CPI All Groups less Credit Services & $\begin{array}{l}1 \text { January each } \\
\text { year }\end{array}$ \\
\hline Motor Spirits excise duty & CPI All Groups less Credit Services & \begin{tabular}{|l|}
1 July 2016, \\
then annually \\
\end{tabular} \\
\hline \multicolumn{3}{|l|}{ Benefits } \\
\hline $\begin{array}{l}\text { Family Tax Credit entitlements within the } \\
\text { Working for Families Package }\end{array}$ & Consumers Price Index & $\begin{array}{l}\text { Normally } 1 \\
\text { April after } \\
\text { cumulative } \\
\text { increase has } \\
\text { occurred }\end{array}$ \\
\hline $\begin{array}{l}\text { War Pensions - Rates of Pensions, Lump Sum } \\
\text { Payments, and Allowances }\end{array}$ & $\begin{array}{l}\text { CPI All Groups excluding cigarettes } \\
\text { and other tobacco products }\end{array}$ & $\begin{array}{l}1 \text { April each } \\
\text { year }\end{array}$ \\
\hline $\begin{array}{l}\text { Social Security - Rates of Benefits and } \\
\text { Allowances (including NZ Super \& Student Loan } \\
\text { living costs) }\end{array}$ & $\begin{array}{l}\text { CPI All Groups excluding cigarettes } \\
\text { and other tobacco products }\end{array}$ & $\begin{array}{l}1 \text { April each } \\
\text { year }\end{array}$ \\
\hline Social Security - Temporary Additional Support & $\begin{array}{l}\text { Actual rentals for the housing } \\
\text { component in the CPI for clause } \\
3(a) \text {; otherwise CPI all Groups } \\
\text { excluding cigarettes and other } \\
\text { tobacco products }\end{array}$ & $\begin{array}{l}1 \text { April each } \\
\text { year }\end{array}$ \\
\hline Social Security - Childcare Assistance & $\begin{array}{l}\text { CPI All Groups excluding cigarettes } \\
\text { and other tobacco products }\end{array}$ & $\begin{array}{l}1 \text { April each } \\
\text { year }\end{array}$ \\
\hline $\begin{array}{l}\text { Home-based care - maximum income } \\
\text { exemption for home-based education and care } \\
\text { of a child }\end{array}$ & $\begin{array}{l}\text { CPI All Groups excluding cigarettes } \\
\text { and other tobacco products }\end{array}$ & $\begin{array}{l}1 \text { April each } \\
\text { year }\end{array}$ \\
\hline Social Security - Long-term residential care & $\begin{array}{l}\text { CPI All Groups excluding cigarettes } \\
\text { and other tobacco products }\end{array}$ & $\begin{array}{l}1 \text { April each } \\
\text { year }\end{array}$ \\
\hline Health Entitlement Cards & $\begin{array}{l}\text { CPI All Groups excluding cigarettes } \\
\text { and other tobacco products }\end{array}$ & $\begin{array}{l}1 \text { April each } \\
\text { year }\end{array}$ \\
\hline
\end{tabular}




\subsection{WHAT IS THE CPI? ('FORM')}

Since its inception the CPI has taken the form of an index number that shows the change in the price of items over time. An index number is a data figure that reflects change in price compared with a 'base value'. The base usually equals 100 (or 1000) and the index number is usually expressed in ratio to the base value. For example, if an item costs twice as much in 1985 as it did in 1975, its index number would be 200 relative to 100 in 1975. One of the key reasons that index numbers are used for the CPI and other statistics is they enable the translation of often complex statistical data into easily understood terms.

As its core the CPI measures the change in price over time of a representative 'basket' of goods and services (referred to technically as the 'regimen'). The representative contents of this 'basket' are chosen to match the conceptual basis of the index. Price change in items which make up a larger proportion of the representative 'basket' will have greater effect on the CPI index number produced than items that make up a smaller proportion of the 'basket'. For example, a 1\% change in the price of petrol in the modern index would have a more consequential effect on the index than a $1 \%$ price change in a less frequently purchased item such as knitting needles.

The 'representative consumer' of the 'basket' is determined by the conceptual basis of the index, which can range from broadly positivist to broadly prescriptive. An aggregate positivist representation of consumers treats money neutrally, meaning the spending patterns of households with greater expenditure have greater influence on the composition of the regimen than households with lesser expenditure. A prescriptive approach on the other hand, sets out what a 'representative consumer' ought to be purchasing and/or designates the spending patterns of a specific sector of the population as the 'representative consumer'. Adjustment of the index 'basket' to adapt to technological change notwithstanding, the political choice of what is and what is not in the representative 'basket' has consequences for its output.

In 1915 the conceptual basis of the index was defined to be the "ordinary necessaries and conventional comforts" that is "required for the mass of the people". ${ }^{33}$ The CPI in 1949 measured price change in "the whole range of commodities and services used in the average household" representing "the

\footnotetext{
${ }^{13}$ Malcolm Fraser, 1915, Report on the Cost of Living in New Zealand 1891-1914, Wellington: Government Printer, p. 7
} 
amenities of modern living" whereas the CPI in 2011 measured "the rate of price change of goods and services purchased by households."

Despite superficial similarities, these conceptual definitions shaped very different statistics. The 1915 CPI was highly prescriptive in examining 'necessaries' and 'conventional comforts', as it was designed to measure price change in what the government defined as the essentials that 'the mass of people' ought require to live. The 1915 CPI eschewed the measurement of price change in what were defined as luxuries such as alcohol, tobacco or holiday travel.

The 1949 version of the CPI moved away from a prescriptive to a more objective approach preferring to measure price change in the 'whole range' of goods and services used in the 'average household' rather than the 'mass of people'. The shift to an average measure, in principle, meant that the households with higher outgoing would have greater influence on the composition of the index over time. At the same time, the presence of the word 'used' meant the index was not solely about what households purchased via a financial transaction, partially grounding the conceptual basis of the index as a 'cost of living' measure. Despite its new objective bent, the measure of price change in alcohol and holiday travel was excluded from the 1949 CPI.

The contemporary form of the CPI represents an almost purely objective measure of price change. The index now measures the change in price of goods and services purchased by households at an aggregate level. Price change representing almost the whole range of goods and services purchased by households are now included in the index, including alcohol and holiday travel. Despite the professed objectivity of the modern index (of which the transition to was a political choice), politics still underpins its composition. Representations of the price change of mortgage interest, gambling and illegal drugs are excluded from the index. While there may be apolitical technical reasons for the non-measurement of the latter two items in the contemporary CPI, the removal of mortgage interest, a 'service' purchased by households that enables ownership of shelter, an essential human need, was ultimately a political decision made because of change to the political function of the CPI.

\subsection{THE CONFLICT BETWEEN FORM AND FUNCTION}

Despite its ubiquity in the contemporary economy the epistemology of the CPI is rarely examined. The CPI as currently produced is commonly seen as an objective 'fact', with its 'accuracy' only constrained by the resources devoted to producing 
the statistic. Aside from those who specialise in its study, there is little discussion or debate over what is actually being measured and how it is done so. It is assumed by many that the CPI measure is the 'best practice', and as the CPI is sealed off from 'politics' (given the statutory independence of the Government Statistician), change in the composition of the index is the consequence of technological innovation. Yet the underlying conception of what the CPI is - how it measures 'inflation', whose 'inflation' the index measures and for what purpose is deeply political.

While the areas of political struggle over a complex statistic such as the CPI can be numerous, essentially the political debate over the purpose of the CPI comes down to tension between the two phenomena the CPI is commonly seen to represent 'inflation' and the 'cost of living' and the functions the index performs to address those two phenomena.

While the CPI is officially defined as a measure of 'inflation', as a convention, the meaning the contemporary CPI conveys is often unclear. From its original conception as a measure of the 'cost of living' the CPI became an official measure of 'household inflation' in the late 1940s. Yet it is still viewed by many New Zealanders as a measure of the 'cost of living. ${ }^{14}$ This is in part due to the continued absence of any official measure of the 'cost of living' and the persistent use of the CPI as a tool to maintain purchasing power through indexation of wages and benefits.

Although often used interchangeably, there are major conceptual differences between the two concepts. Essentially, the CPI as 'inflation' is a positivist approach that measures the 'cost of stuff' by treating (almost) every dollar spent by households equally irrespective of the essentiality of goods and services purchased. A 'cost of living' approach is more prescriptive in that it measures the price change in maintaining a set amount of utility or satisfaction.

Even in its positivist guise as a measure of 'household inflation' the CPI is used in used in ways that would not have been anticipated by its creators. Arguably the most consequential use of the contemporary index is as a monetary policy 'target' for the Reserve Bank, where the Governor of the bank is contractually required to keep 'underlying' CPI inflation between 1 and 3 per cent per annum. ${ }^{15}$ Yet the CPI only measures inflation in households which comprise approximately $60 \%$ of New

\footnotetext{
${ }^{14}$ Rob Stock, 2013, 'One-size CPI doesn't fit all', Sunday Star Times, August 18 2013, http://www.stuff.co.nz/business/industries/9059046/One-size-CPI-doesn-t-fit-all

${ }^{15}$ Reserve Bank of New Zealand, 2012, 'Current Policy Targets Agreement', September 2012, http://rbnz.govt.nz/monetary policy/policy targets agreement/4944826.pdf
} 
Zealand's economic activity. Therefore the CPI is used, in effect, to determine the price of money for the entire economy.

The choice to use the CPI as a 'target' monetary policy was essentially political, it was selected by politicians to be the yardstick for the Bank not because of its intrinsic qualities as an economic 'rule' but rather due to the index's public acceptance as a 'convention' for measuring price change.

The common view of the CPI as a measure of the 'cost of living' suggests that official change to the CPI 'rules' does not necessarily lead to change to the CPI as a 'convention'. The changes to the composition of the CPI that stemmed from its use in monetary policy shows that the political role of the CPI as a 'convention' can, in turn, change the 'rules' of the CPI. The most significant recent change to the CPI, the removal of mortgage interest from its scope, has meant that that cumulative inflation, as measured by the CPI from 2009 to mid-2014 (in a time of low interest rates), was $11.2 \%$ rather than $7.1 \%$, far higher than it otherwise would have been. ${ }^{16}$

\subsection{EMPIRCAL RESEARCH QUESTIONS}

This research provides an examination of change in the measurement of inflation in New Zealand demonstrating how development of the CPI has been driven primarily by the machinations of politics rather than technological change. It analyses two significant periods of change in the design and usage of the CPI, demonstrating why the form of the index has been primarily the outcome of politics. It examines the economic and political power structures underlying the form and function of inflation measurement, and how change in those structures has precipitated change in the CPI.

In addressing the story of change in how inflation is measured in New Zealand, I propose the following hypothesis: The measurement of inflation and the 'cost of living' is inherently political. Over time, New Zealand's Consumers Price Index has been affected by change in economic and political power, both domestic and international. The political functions that the CPI performs are determined by the outcome of political conflict which ultimately dictates the design and form of the statistic. As the power of institutions and political groupings increased and decreased, as did their influence over how price change was measured. When the CPI was initially devised in the 1910s, the political and economic influence of the British Empire was prevalent over the Dominion of New Zealand, whereas later

\footnotetext{
${ }^{16}$ Statistics New Zealand Infoshare, 'CPI All-groups' vs. 'CPI plus interest', 2009 Q1 to 2014 Q2.
} 
developments in the CPI in the era surrounding World War II, power transmitted through international organisations such as the ILO and the United Nations had greater influence.

As political and economic power among workers, employers and financiers changed, as did their influence on the CPI. When the CPI had a direct impact on wage-setting through the Court of Arbitration, union and employer influence on the measurement of inflation was strong, whereas as the political strength of unions ebbed in the 1990s, and the financialisation of the New Zealand economy increased, changes to the index largely favoured the interests of finance over workers. The consequential choices regarding the technological development of the CPI have always been inherently political, linked to the contemporary and historical political and economic power of institutions.

The premise of this thesis is that politics changes technology, specifically that political struggle over time has changed how inflation is measured in New Zealand via the Consumers Price Index.

To demonstrate this, two specific case studies will be presented from two distinct periods in the CPI's 100-year history: Firstly, the transformation of the index from a prescriptive tool of social assessment that measured the 'cost of living' during World War I to an objective economic measure of inflation in the aftermath of World War II. This will be followed by an examination of the circumstances surrounding the political decisions that led to the removal of the measurement of price change in mortgage interest payments from the index in 1999, the only major reduction in the scope of the index's 'basket of goods' in its history.

The choice of empirical research questions and these particular case studies is dictated in part by the constraints of the scope of the Master's thesis programme and by the largely underdeveloped existing body of research into the political economy of price indexes both in New Zealand and elsewhere.

To test this hypothesis this thesis will demonstrate the links between change in the function of the CPI with New Zealand's position in the international economy and the structure of New Zealand's domestic politics. I will explore the following research questions to demonstrate the power structures underlying the form and function of the Consumers Price Index and the causes of change in the measurement of inflation:

1. Is change in New Zealand's CPI driven primarily by technological improvement or is it primarily driven by politics? 
2. Why did the basis of the CPI changed from a generally prescriptive measure of the 'cost of living' to a generally positivist measure of 'inflation'?

3. Why did the removal of mortgage interest from the CPI regimen in 1999 occur?

4. How has the process of change in the CPI occurred?

In addressing these questions, this thesis will provide empirical evidence demonstrating the power structures underlying New Zealand's economy and polity, and the overwhelming influence these structures have on the measurement of inflation its governance. In conducting this research, I must show awareness of evidence that is contrary of the tenets of the hypothesis that prove it inaccurate or incorrect. Where these instances arise, I will assess whether they undermine the linkages between the tenets underlying the argument of thesis.

These questions seek to determine what political mechanisms, if any, have influenced the measurement of price change in New Zealand. These approach will examine whether the evolution of the Consumers Price Index is a case of technology influencing politics or instead has politics shaped technology? Through the use of two distinct case studies this thesis examines the mechanisms that have influenced the form and function of the CPI has during its early years as well as its contemporary presence function.

\subsection{EMPRICAL LITERATURE REVIEW}

Despite the significant redistributive consequence of the CPI to New Zealand's economy and the continuous development of the statistic over the past century, until recently little attention has been paid to the intersection between politics and the epistemology of the index. In part, this is due to the cross-cutting nature of the politics of economic statistics, reaching across the fields of economic, historical and political research.

When cited in economic histories of New Zealand and elsewhere, the CPI and other related statistics tend to be treated as apolitical institutions that neutrally measure economic phenomena over time, with change occurring as part of an ongoing process of 'technological improvement' with little regard for the political environment surrounding that change. In political histories of labour movements and institutions in New Zealand, the discussion of the role of the CPI within the Court of Arbitration, for example, is often detached from the conflict between labour and capital that surrounded the role of the court itself. This study places the 
history of change in the CPI within the contemporary political and social context it occurred within.

Within the social sciences, the history of statistics is a common topic, for example there are numerous studies that examine the origins of social surveys particularly in the period spanning the end of the $19^{\text {th }}$ and beginning of the $20^{\text {th }}$ centuries..$^{1718}$ Many of these works focus more on the organisation of and the political forces behind these surveys rather than the methodology of the data produced and collected. But they do inform the study of the CPI as the origin of the statistic has direct links to an underlying purpose of identifying social need through information collection. Much of the findings of this research traces the transition from initiation by non-state actors towards social data being collected and controlled by the state, which parallels the early history of the CPI. In a similar vein, studies of the history of censuses are also important, as the first governmental constructions of the CPI in New Zealand were conducted by the census office. ${ }^{19}$

In New Zealand, there are several examinations of institutions that have been influential in the history of CPI change, many of which make reference to the role of the index. These include studies of the Court of Arbitration, the Department of Labour, the Treasury and the Reserve Bank of New Zealand. ${ }^{20} 2122$ Alongside these institutional studies are economic histories that coherently link the political environment to change in state and non-state institutions. ${ }^{23}$

Internationally, there is a small but growing body of study into the politics of statistics. Some studies that take a high level approach have formed general hypotheses regarding the use and construction of official statistics but are hamstrung from making detailed findings due to the lack of detailed domestic studies of individual statistics. ${ }^{24}$ But studies that focus on specific statistics at the national level are beginning to increase, in particular, examination of the American

\footnotetext{
${ }^{17}$ Michael J. Cullen, 1975. The statistical movement in early Victorian Britain: the foundations of empirical social research. Hassocks, Sussex: Harvester Press.

${ }^{18}$ Evan Roberts, 2014, 'Making Weights: Family Budget Studies in New Zealand 1893-1937', in Sharleen Forbes, and Antong Victorio (eds), The New Zealand CPI at 100: History and Interpretation, Wellington: Victoria University Press, 2014

${ }^{19}$ A.J. Christopher, 2008, 'The quest for a census of the British Empire c.1840 - 1940', Journal of Historical Geography, Vol. 34

${ }^{20}$ Noel S. Woods, 1963, Industrial conciliation and arbitration in New Zealand, Wellington: Government Printer.

${ }^{21}$ John E. Martin, 2010, Honouring the Contract, Wellington: Victoria University Press.

22 John, Singleton, 2006, Innovation and Independence: The Reserve Bank of New Zealand 1973-2002.

Auckland: Auckland University Press

${ }^{23}$ Brian Easton, 1997, The Commercialisation of New Zealand, Auckland: Auckland University Press

${ }^{24}$ Zachary Karabell, 2013, The Leading Indicators: A Short History of the Numbers That Rule Our World, New York: Simon \& Schuster.
} 
CPI in a political context is becoming more developed. ${ }^{25}$ As more studies of the CPI (and other official statistics) at the national level become more prevalent, greater study of the role of official statistics and the macro and global level will be able to be undertaken. This thesis will make a contribution to this body of knowledge.

In New Zealand, the study of the history of the epistolomology of the CPI has until recently been largely unexamined. There are a smattering of descriptive studies regarding the history of statistics in New Zealand including a number of official works commissioned by Statistics New Zealand and an informal but informative, autobiography of the former Government Statistician, George Wood. ${ }^{26}$ There are also a number of technical and economic studies of the CPI, some which form part of the official reviews of the CPI conducted regularly by Statistics New Zealand.

The CPI celebrated its 100 year anniversary as an official government statistic in July 2014. As part of the commemorations, Statistics New Zealand commissioned a special research project into the history of the statistic, of which a principal output was a volume of essays that looked at the role of the CPI from a number of different social, economic and technical viewpoints. ${ }^{27}$ This thesis is in part, a consequence of that project. This work utilises much of that primary research and secondary analysis. The author of this thesis, who was attached to the research project, acknowledges and thanks those that allowed me the opportunity to be part of that programme.

\subsection{A HISTORICAL INSTITUTIONALIST RESEARCH APPROACH}

Although this thesis will first and foremost address the substantive empirical questions raised above, it is also theoretically motivated and will contribute to debates relating to the theory of change in institutions.

There is no universally accepted definition of an 'institution' in social sciences. However, as T.R. Voss argues, there are generally two perspectives of institutions firstly, institutions as the 'rules of the game' - constraints upon human interaction that "involve mutually related rights and obligations" allowing the organisation of

\footnotetext{
${ }^{25}$ Thomas A. Stapleford, 2009, The Cost of Living in America, New York: Cambridge University Press

${ }^{26}$ George Wood, 1976, Progress in official statistics, 1840-1957 : a personal history, Wellington: Department of Statistics

${ }^{27}$ Sharleen Forbes, and Antong Victorio (eds), 2014, The New Zealand CPI at 100: History and Interpretation, Wellington: Victoria University Press
} 
society in a predictable manner. ${ }^{28}$ Secondly, institutions are the equilibrium or 'convention' that results from adherence to these rules, creating expectations for 'normal' conduct. Essentially, institutions are both 'rules' and 'conventions' for human interaction that encapsulate expectations for human behaviour.

Institutions, of course, do not have to be governed by formalised rules. For example the performance of a karakia and the removal of footwear upon entering a marae is not governed by formal legislation but by social and cultural expectations that have developed over centuries. This study of the CPI, however, is principally concerned with change in the formal 'rules' of institutions as they are related to social 'conventions', in particular political conflict and historical context.

The differing approaches to the study of institutions have implications for the methodological approach to the study of CPI change. Three broad perspectives are identified in much of the literature on 'new institutionalisms'. Although these categories are not exclusive and overlap to an extent, distinguishing between the approaches is important because of the difference in assumptions that underlie these perspectives.

A broad evaluation of the approaches is provided by Hall and Taylor. ${ }^{29}$ The authors distinguish between two core issues that relate to institutions: the role of institutions in determining 'social and political outcomes' and the behaviour of actors and secondly, how institutions are created and the circumstances under which change occurs. Although this study is primarily concerned with the second issue, there are strong links between both aspects.

Hall and Taylor observe that despite some overlap between them, the three approaches are highly polarised, having developed somewhat 'independently' from each other which is reflected in the disciplines commonly associated with the approaches. Broadly, rational choice institutionalism tends to be associated with economics, normative institutionalism with sociology and historical institutionalism with political science.

Rational choice institutionalism assumes that actors operate with rational selfinterest and fixed preferences and behave so as to maximise the attainment of those preferences. Under this perspective, institutions are voluntarily created by the mutual agreement of relevant actors to perform a function that will resolve a

\footnotetext{
${ }^{28}$ T. R. Voss, 2001, 'Institutions' in N. J. Smelser (ed.) ,International Encyclopedia of the Social \& Behavioral Sciences, Amsterdam: Elsevier Science, pp.7561-7566

${ }^{29}$ Peter A Hall and Rosemary C R Taylor, 1996, 'Political Science and the Three New Institutionalisms', Political Studies 44(5), pp. 936-957.
} 
collective action problem and ensure mutually beneficial gain. Institutions are assumed to exist so long as the associated actors continue to benefit from them. Explanations of institutional change are linked to shifts in the pay-offs received by actors which may prompt them to reshape the institution to meet changing interests. Rational choice, therefore, is a highly functionalist approach although it has been criticised as empirically insignificant and overly simplistic. ${ }^{30}$

In contrast, normative institutionalism tends to entail little reference to rationality or functionalism. This approach views institutions as 'culturally-specific' practices that are the 'forms, procedures or symbols' that embedded within organisations. This approach entails a definition of institutions that includes 'symbol systems, cognitive scripts, and moral templates that provide the frames of meaning for guiding human interaction', a scope wider than the formal rules, procedures and norms typically defined by the rational and historical approaches. Institutions are seen to influence the behaviour of individuals through the internalisation of norms that are associated with particular roles. In contrast to the rational approach the motivation for the creation and maintenance of an institution is to increase the 'social-legitimacy' of associated actors rather than 'efficiency'. This approach can explain why particular institutions are maintained despite detracting from the goals and preferences of the associated actors. On the other hand a weakness of this approach is the understatement of agency within actors. The normative approach views agency as something that is conditioned by respective institutions. Therefore power-political conflicts within particular institutional arrangements tend to be overlooked under this approach.

Historical institutionalism (HI), as the name suggests, depicts temporal processes and historical events as critical in shaping the institutions that inform preferences. Therefore actors behave according to the institutional rules that define their strategies and unlike the rationalist approach, HI recognises the historical presence and legacies of institutions.

HI also entails broader assumptions on the effect of institutions on actor behaviour. Asymmetries in power relations shape how institutions are created and developed. Other variables, such as ideas and the complexities of institutional and individual behaviour tend to be integrated in this type of institutional analysis. A common critique of this approach is the propensity to generalise rather than making coherent theoretical contributions. Furthermore, HI has tended to place a strong emphasis on path-dependence and reinforcing mechanisms which

${ }^{30} \mathrm{Ibid}$. 
contributes to a static view of institutions. A strength of the HI approach is that it has been very strong in explaining continuity in institutions, but as some have argued, this has come at the expense of explaining change and transformation.

Thus the three approaches hold broadly differing assumptions on the role of actors, the reasons for the formation of institutions, why they are maintained and why change or continuity occurs. But there is reasonable consensus (at least between $\mathrm{HI}$ and rational choice) that the mechanisms for institutional change and continuity are far from being well understood.

Examining the development of the CPI through each of these competing schools of thought would be the ideal for the study of the CPI as an institution. But given the limitation of the scope of the Masters' thesis, the longevity of the CPI and the paucity of pre-existing literature specifically devoted to the topic, it is preferable to narrow the focus to one approach. The relevance of historical and institutional legacies makes HI the most relevant approach to the study of New Zealand's Consumers Prices Index. In addition the developing emphasis on the on the role of agents and the study of incremental change in the field of HI makes change in the CPI likely to provide the most informative contribution among the three main 'schools' of thought in institutionalism.

\subsection{REVIEW OF LITERATURE REGARDING INSTITUTIONAL CHANGE}

The political economy of New Zealand's CPI is an example of institutional change that can inform and further research into the study of the theory of institutions. Over its history the CPI has undergone change relatively frequently to maintain its political and economic relevance and forestall exhaustion. The changing construction of New Zealand's CPI also has clear international and domestic political influences. On first glance, the CPI appears to undergo significant and sudden change in response to external exogenous shocks, such as globally driven price change that are linked to events such as wars and economic depressions. But many of the changes to the CPI may be caused by incrementally introduced ambiguities in its form and function. The CPI as an institution is quixotic, it simultaneously has informal and formal uses, and the outcomes it produces often have high political salience. Yet the debate over its construction and epistemology often resides in the domain of 'quiet politics' among vested interests and policy makers, even as it maintains ubiquity among the wider public as a measure that has consequential impact on economic redistribution. 
The study of historical change in economic and political institutions is not new. There is a growing literature within the field of HI that attempts to explain the reasons for institutional change in economic institutions. Broadly, there are two areas of thought on institutional change within the field of HI. There is an argument that institutions are often 'locked into' path dependence and significant institutional change occurs as a result of exogenous shocks. ${ }^{31}$ On the other hand change can be said to occur as a consequence of on-going incremental change. Both of these approaches are central to the literature on institutional change in developed economies.

One of the most prominent and influential incremental perspectives is the work of Thelen that examined the development of the German apprenticeship system finding that although developed for one purpose the institution ultimately became something much different. Thelen found that institutional change is not necessarily caused by disruption but can occur incrementally and changes that may appear minor cumulatively recast institutions with significant consequences for economies and society. ${ }^{32}$

Baumgartner and Jones argue that that the model of punctuated equilibrium shows that institutions remain stable over time but can change by a sudden societal or governmental shift. ${ }^{33}$ Punctuated change, which is often linked to the analysis of 'critical junctures' suggests that institutions are inherently stable and sticky, bounded by the rationality of interest groups and policymakers, with change largely prompted by a shock to the prevailing system.

The critical juncture framework views institutional change as being rooted in prior crises and cleavages with its cause linked to a weakness in the status quo. ${ }^{34}$ An exogenous shock occurs which necessitates change for its resolution. Critical junctures are changes that resolve problems and set in place that inaugurate the new 'normal'. A punctuated change occurs because it serves a need or for change to a system instigated by a crisis. This approach is broadly functionalist; the punctuated change of a critical juncture addresses problems related to prior political decisions and events. The prevailing order cannot sustain itself and thus

\footnotetext{
${ }^{31}$ Paul Pierson, 2000, 'Increasing Returns, Path Dependence, and the Study of Politics', The American Political Science Review, Vol. 94, No.2, pp. 251-267

32 Kathleen Thelen, 2004, How Institutions Evolve: The Political Economy of Skills in Germany, Britain and Japan, Cambridge: Cambridge University Press

${ }^{33}$ Frank Baumgartner and Bryan D. Jones, 1993, Agendas and Instability in American Politics, Chicago: University of Chicago Press

${ }^{34}$ David Collier and Ruth Berins Collier, 1991, Shaping the Political Arena: Critical Junctures, the Labor Movement, and Regime Dynamics in Latin America, Princeton: Princeton University Press.
} 
must shed the old, to reveal a new skin. Elements that echo this argument have also crossed over into popular culture with the idea of 'disruptive' change that is especially popular in technological circles in North America such as 'Silicon Valley' ${ }^{35}$

The incrementalist argument is an actor-centred theory that argues that institutions undergo continuous but gradual change over time. There are on-going struggles and choices made among opportunistic actors that attempt to alter the institution or maintain the status quo which can result in significant and consequential change to institutions. This argument, put most forcefully by Mahoney and Thelen argues that institutional change commonly occurs due to ambiguities in rule interpretation and enforcement when allows space for actors to implement existing rules in new ways. ${ }^{36}$ Thus institutional change and outcomes do not necessarily reflect the aims of any particular group of actors, they instead may be the unintended consequence of conflict between groups or compromises among actors who coordinate on institutional construction despite differing on substantive goals. Perceived stability institutional stability not only relies upon accumulation and mobilisation of power and resources, as does change. Therefore shifts in the balance of power between actors over time can result in institutional change.

This intent of this thesis is to address the theoretical puzzle of institutional change in the CPI from both the incrementalist and path dependence-punctuated change perspectives. The Mahoney and Thelen framework that links the characteristics of the institution and the political context with the type of dominant change agents and the resulting type of institutional change will be tested against the case studies of change in the CPI and the alternative explanation of punctuated change.

While it is acknowledged that two approaches to change are not necessarily opposed, and are in some ways complementary, ${ }^{37}$ there are shortcomings in the two approaches. For example, under the punctuated change theory, the definition is often fuzzy as to when change is said to be major and the threshold above which defines a sudden change. On the incrementalist side, it is often unclear what change is considered to be incremental rather than sudden. It is at times unclear what a major change is defined as because what could be the result of the

\footnotetext{
35 Jill Lepore, 2014, 'The Disruption Machine', The New Yorker, June 23 2014, http://www.newyorker.com/magazine/2014/06/23/the-disruption-machine

36 James Mahoney and Kathleen Thelen, 2009, Explaining Institutional Change: Ambiguity, Agency, and Power, Cambridge: Cambridge University Press

37 Jeroen Van Der Heijden, 2010. 'A short history of studying incremental institutional change: Does Explaining Institutional Change provide any new explanations?' Regulation \& Governance 4(2), pp. 230-243
} 
accumulation of small changes may over time, combine to reach a tipping point that appears to produce 'sudden' change.

An approach from the incrementalist perspective, articulated by Thelen and Mahoney, has the potential to overcome the shortcoming of these definitional issues that may suit the study of change in statistical institutions such as the CPI. This model for gradual transformative change encompasses five broadly defined modes of change: 'layering', 'conversion', 'drift', 'displacement' and 'exhaustion'. These types of change are linked to the on-going discretion of institutional rule interpretation and enforcement as well as the relative strength of political actors. ${ }^{38}$ These approaches are all based around incremental endogenous shifts in power and thinking over long periods of time.

Displacement of an institution tends to emanate from a shift in power where the prevalent power is undermined in favour of a new paradigm. This may occur as a consequence of new actors creating or reactivating new systems or approaches towards an institution. Exhaustion as a process often leads to the breakdown of an institution rather than change, although this is gradual rather than abrupt. Over time institutions may become unaware of the changing political and economic context and are unprepared for the future. Drift can result from ambiguities in processes that cause actors to alter their previous duties or responsibilities. Drift need not only occur through political actions but also through subtle changes in the political context and environment.

Layering is defined as to be when forms, functions, rules and outcomes are added upon an existing institution that has previously appeared to be intractable to change. New functions are introduced alongside immoveable old ones, and although the new processes were not originally intended to supplant the old, the effect creates a new dynamic among actors that ultimately leads to significant institutional change. Layering appears to fill the void between the intentions and outcomes of institutions by arguing that existing institutions are not replaced wholesale, but that new 'layers', such as that change outcomes incrementally over time.

Conversion is where an institution is redirected to new functions or purposes. This redirection can be a result of changes in political dynamics and context. This is different from layering in that it is the institution rather than the actors that adapts to the new political context. The redirection of purpose may in turn create further

\footnotetext{
38 James Mahoney and Kathleen Thelen, 2009, Explaining Institutional Change: Ambiguity, Agency, and Power, Cambridge: Cambridge University Press, Chapter 1
} 
political struggle in what the function of the institution should be. This can lead to compromise among actors and interest to mitigate ambiguities in the enforcement and interpretation of rules.

Given the multiple roles of the CPI over time, both formal and informal, in the indexation of incomes, as an economic and social indicator, and a monetary policy tool, the 'layering' and 'conversion' approaches appear to be useful devices for examining incremental change in the CPI as an institution. This thesis will primarily test these incrementalist approaches against the case studies of change in the CPI, while acknowledging that other alternatives such as drift and displacement may also serve as more useful theoretical explanations. Although the primary theoretical examination of these case studies regards incremental change, the 'sudden' change models of path dependence and punctuated equilibrium will also be evaluated as a contrast.

In addition, it must be acknowledged that there are many areas of institutional study that this thesis will not address including the preference formation of interest groups and actors as well as other perspectives and explanations for institutional change within HI and other schools of institutionalism.

\subsection{THEORETICAL RESEARCH QUESTIONS}

The theoretical questions this thesis will address are as follows:

1) Are these significant changes in the CPI examples of sudden or incremental change?

2) Does 'path dependence' or 'layering and conversion' adequately explain the process of institutional change in the CPI?

Not only will this thesis contribute to the existing body of work on the political economy of official statistics, it will also broaden and add to the study of institutional change theory. 
CHAPTER 3 - INCEPTION AND ENTRENCHEMENT: THE CPI AND NEW ZEALAND'S POLTICAL ECONOMY 1891 - 1949

\subsection{SUMMARY}

This chapter will identify and evaluate the processes and sources of political change to the CPI in the first half of the $20^{\text {th }}$ Century. It will examine the circumstances that surrounded the creation of the index in the 1910s, its consolidation and transformation into a consequential distributive tool, and the subsequent formalisation into an official statistic of the state in the post-WWII era. Explanations as to why the CPI, which began as a subjective social tool of examination in 1910s ultimately became an objective mechanism of economic redistribution will be proffered with a focus on changing political environment and balance of power among interest groups, actors and institutions. This case study is evaluated against explanations of institutional change that assess how change in the index occurred and how the outcome of change related to the process of change. The chapter concludes by assessing whether this episode of institutional change was primarily caused by the 'shock' of exogenous events or whether it was the consequence of incremental change generated endogenously through constant struggle between interests, ideas and institutions.

\subsection{THE 'SIGNIFICANT CHANGE'}

Following the conclusion of World War II, a government-appointed committee tasked with devising a revised 'cost of living' measure for the post-war era, proposed significant changes to the New Zealand's official price index, which was renamed to the 'Consumers Price Index'. What had been a prescriptive statistic of social investigation that measured price change in what households should consume became a positivist economic statistic that measured the price change of the goods and services that households actually consume. This change was generally supported by most of the dominant actors that ultimately determined the structure of the CPI including the Court of Arbitration, the Government Statistician, employer groups and unions as well as international bodies and of course the Cabinet of the New Zealand Government.

The process of technological change through political struggle began soon after the CPI was first conceived in the 1910s and intensified as the political and economic consequences of the statistic increased leading to significant change as the balance of power shifted among influential actors. 


\subsection{THE EARLY YEARS OF CPI DEVELOPMENT}

Social statistics underwent rapid development in the United Kingdom and elsewhere during the nineteenth century as important new methods for gathering information about the population. Although the idea of counting and categorising information relating to the conditions of life was not in itself a new idea as demographic studies, for example, were developed during the seventeenth and eighteenth centuries, the nineteenth century saw what were once intermittent attempts to assess social ills in the United Kingdom organised into systematic measures of society that were used to inform government policy. This was based on the belief that numerical facts provided a rational basis to identify social trends. For example, the collection of a British census commenced in 1801 and by the 1830s statistical societies began to form. Often in co-ordination with the British government, such societies provided information to parliamentary committees. Large-scale statistical work was also undertaken, such as the royal commissions into the Poor Laws and the condition of the Irish poor, and within the factory inspection system. Government departments then began to set up their own statistical sections, such as in the Home Office and the Board of Trade, and a General Register Office was established to centrally collate information on births, deaths and marriages.

Soon after the British assumed governance of the colonies of New Zealand in 1840, the systematic collection of prices began. 'Blue Books' of essential data regarding the new colonies were composed and sent back to the Home Office in the United Kingdom annually from the 1850s onwards. As New Zealand became more integrated and reliant upon the Imperial economy, it experienced the cyclical effects of the global economic system. Through the 'Long Depression' of the 1880s New Zealand suffered high levels of unemployment spurring large-scale emigration to Australia. Although often disorganised, sporadic and shirt in duration, the frequency of strike action and industrial unrest increased and trade unions began to form and attempt to gain legal recognition. This coincided with growing elite and public concern around social unrest and the standard of living for New Zealanders.

\subsection{ASSESSING SOCIAL ILLS IN 'BET'TER BRITAIN'}

The impetus for statistical assessment of social ills began in earnest in the 1890s with the election of the Liberal government. Although seeing themselves as 'British', many politicians within New Zealand's first party-based government saw themselves as pioneers intent in establishing a 'new world' free from 'old world' 
'evils' such as landed monopolies. A series of radical social and economic reforms were introduced including women's suffrage, expansion of worker's rights through a court of arbitration and the establishment of a national pension system. While the intent of these policies was in part designed to stem the exodus to Australia and protect workers' standards of living, decades later, these reforms would all have implications on the direction of the CPI.

Even though many of the reforms of the Liberal government were world-leading, they were greatly motivated by trends from the United Kingdom and elsewhere. For example, the idea of 'an industrial army of labour' was derived from the fledging British Fabian movement which was a significant influence on many New Zealand political elites in the 1890s. Yet while working and social conditions were not of a high standard for many New Zealanders at the time, the social ills in the largely agricultural colony differed in many respects from the industrialised 'old world'.

This tendency among elites to replicate contemporary British concerns in colonial New Zealand society explains the establishment and approach of a Royal Commission in 1890 that investigated the problems of 'sweating' (exploitation of workers via long wages and long hours). Despite a largely rural economy with small-scale industries and few large factories, "it was the fear of what might happen, rather than the reality, which motivated policy". ${ }^{39}$ This commission borrowed many of the techniques and approaches of social investigation that had been developed in the United Kingdom throughout the century. But the underdeveloped nature of the New Zealand state allowed elite politicians and officials are freer hand in the design of organisations through which they hoped to create a 'better Britain'.

\subsection{THE ROLE OF THE LABOUR DEPARTMENT}

The principal outcome of the 'rational' studies of the Sweating Commission was the creation of a department of labour to oversee the labour market and reduce unemployment. The Commission also proposed the creation of a dedicated statistical department similar to those already established in Australian states to assess living and working conditions through scientific methods, although this recommendation was not taken up. ${ }^{40}$ The new labour department did however, incorporate some data gathering roles akin to the British Board of Trade. Liberal

\footnotetext{
${ }^{39}$ Martin, Holding the Balance, pp. 138-140

${ }^{40}$ Appendices to the Journals of the House of Representatives, 1890, 'Report of Royal Commission investigation into Sweating', H-5, p. vi
} 
leader John Ballance claimed the department would be a "special office for the collection of all information connected to industry, in the nature of a Bureau d'Industrie, which has been established in many European countries and found to work well" although this did not eventuate. ${ }^{41}$ During the 1890 s, the raft of employment legislation enacted such as compulsory arbitration and 'anti-sweating' regulations required considerable administration and enforcement that consumed much of the new labour department's resources which relegated data collection to a secondary priority. This pushed the department to favour the haphazard methodology of voluntary collection and submission of data rather than sampling households, workplaces and merchants in a systemic manner.

Despite the lower priority ascribed to data collection, the department undertook a number of studies that influenced the early form of the CPI. The first hints at the conceptual basis of what would become the CPI can be seen in the family budget study conducted by the Department of Labour in $1893 .{ }^{42}$ 'Returns of Expenditure by Working-Men', although crude by modern standards was a study of comparable quality to contemporary studies conducted by social scientists in the United States and Europe. This is because the study, right down to its methodology and choice of commodity prices measured was a duplicate of an 1889 investigation conducted by the UK Board of Trade. ${ }^{43}$ Aside from a more conservative treatment of alcohol (New Zealand only measured alcohol consumed in the home) and an arbitrary division of families based on incomes below or above 100 pounds, very little in the study was customised for New Zealand conditions. This 'copy-andpaste' of methodology meant the underlying conceptual principles behind the British initiative were transferred unchanged into the measurement of New Zealand economic conditions. While the content of what was measured in the budget studies was not entirely suitable for New Zealand, (for example New Zealanders caught and grew their own food at a far higher proportion than the British) it did mean that fledgling colony was able to quickly implement relatively modern research techniques in the field.

Acknowledgement of the importance of the urban working class in the functioning of the economy were the basis of many European and American budget studies in the late 19th and early 20th centuries. Thus as the British Board of Trade study was based on an 1853 International Statistics Institute resolution stating that "in every country means should be devised to lay the foundations of domestic

\footnotetext{
${ }^{41}$ Martin, Holding the Balance, pp. 17-19

${ }^{42}$ Appendices to the Journals of the House of Representatives, 1893, Report of the Department of Labour, H-10

${ }^{43}$ British Parliamentary Papers, 'Returns of Expenditure by Working Men', 1889, C.5861
} 
economy among the working classes" so too was New Zealand's budget

study. ${ }^{44}$ The focus on a 'working class' standard of living was compatible with the raison d'être of the Department of Labour and this preoccupation carried over into the nascent development of a national price index.

In 1903 a survey of merchants and landlords was carried out in order to estimate the price change of 'necessaries' over the previous ten years. Percentage price changes for individual items and rental types were provided that ranged from no change in the price of tobacco, a 25 per cent increase in rental housing to a 50 per cent increase in the price of firewood. ${ }^{45}$ Matching the subjective and arguably paternalistic trend of social surveys of the time, these surveys set the tone for 'cost of living' studies in New Zealand. These two studies also demonstrated the ambition of the state to establish the costs for a working family to meet its basic needs in order to determine the necessary level of wages.

As the labour laws of the 1890s gradually became normalised and unemployment reduced in the early 1900s, the labour department looked to expand its statistical and information gathering role. ${ }^{46}$ But without the powers of compulsion enjoyed by their overseas counterparts, the department faced continued problems in collecting data from employers and merchants so as to report upon social conditions. Many employers viewed the department with suspicion feeling it was biased towards the side of workers which hindered its statistical gathering capacity. Despite urgings from unions and the head of the department to grant greater power, when the department's legislation was amended in 1905, only limited scope was granted to the office to compel the collection of data. ${ }^{47}$ Unlike in other countries such as the United States where the Bureau of Labour Statistics led the development of the US CPI, the curtailing of the statistical powers of the New Zealand labour department ultimately meant it would not lead the construction of the New Zealand CPI.

\subsection{THE FIRST PRICE INDEX}

With the problem of unemployment receding and the prices of commodities increasing the 'cost of living' began to become a contentious political issue in the first decade of the 20th Century. Unions were critical of wage award decisions handed down by the new Court of Arbitration feeling they had not kept pace with

\footnotetext{
44 'Returns of Expenditure by Working Men', 1889, p. 48

${ }^{45}$ Appendices to the Journals of the House of Representatives, 1903, Report of the Department of Labour, H-10

${ }^{46}$ Martin, Holding the Balance, pp. 78-79

${ }^{47}$ Ibid.
} 
changes in the cost of living. ${ }^{48}$ In response the Minister of Internal Affairs commissioned the Registrar-General (who at the time had responsibility for official statistics) to create a price index of 'basic items' to compare with wage awards over the past decade so as to assess the validity of the unions' claims. At a series of public meetings in 1908 regarding the Labour and the Arbitration Act, the Minister cited these index figures to claim that awards by the Court of Arbitration had kept pace with the increased cost of living and nor were the Court's decisions responsible for price change. ${ }^{49}$ The index was extremely crude containing just nine food items with prices collected by police as part of the 1906 census. ${ }^{50}$ But the citation of an 'index' to justify government policy indicates some level of familiarity among the public and elites with the concept. For example, price indexes had been mentioned for some time in local newspaper articles regarding local and international research into price change. ${ }^{51}$

\subsection{STUDYING THE 'COST OF LIVING'}

Perhaps the most significant event for the early development of New Zealand's national price index occurred in another country. With the states and territories of Australia becoming a federation in 1901, a federal statistics agency was established in 1905 to co-ordinate the activities of the pre-existing state statistical agencies. Although it would be 50 years until the Commonwealth Bureau of Census and Statistics would entirely assimilate the state agencies, the creation of a central office was critical for efforts at standardising statistical methods across both Australia and New Zealand. Prior to its creation, the individual states of Australia had compiled and published statistics for their own use and a series of conferences with representations from state agencies (including New Zealand's Registrar General) were used to co-ordinate efforts. The new federal agency took over the conference co-ordinating role and used its powers to forward several initiatives under the stewardship of renowned Commonwealth Statistician George Knibbs. Among the early initiatives were an investigation into the cost of living and the development of a retail price index. The frequency of state policy transfer between Australia and New Zealand due to their shared colonial histories, close

\footnotetext{
${ }^{48}$ Martin, Holding the Balance, p. 85

${ }^{49}$ The Wanganui Herald, 1908, 'Labour and the Arbitration Act: Address by the Hon. Dr. Finlay', May 231908 , pp. 5-6

${ }^{50}$ New Zealand Official Yearbook, 1908, Wellington, Government Printer, p. 540

${ }^{51}$ Otago Witness, 1894, 'The Financial Depression and the Theory of Value', 26 July 1894, p. 51
} 
professional and social links and similarity of the two societies meant it was not long until the statistical investigations were replicated across the Tasman. ${ }^{52}$

Although attempts to strengthen the statistical capacity of the Department of Labour were stymied in the early 1900s, in 1911 the department embarked on an investigation into the 'cost of living' problem so as to "present the public reliable data as to the cost of living". ${ }^{53}$ The methodology of the study was influenced by a similar Australian cost of living investigation that commenced in mid-

1910. Department of Labour officials were dispatched to Australia to learn from Knibbs and his office which supplied complete information on the methodology and techniques being employed in the survey. While the New Zealand inquiry appeared highly derivative of the Australian version, even down to the layout and formatting of the published report, there were some significant differences.

While the Australia study did not set limits to the level or sources of income of the surveyed households, the New Zealand survey narrowed the concept of 'living' to that of a nuclear family, with income neither too high nor too low, that paid rent and was supported by a father in stable employment. The response rate for this budget survey of households of "bona fide workers" was poor with just 69 of 1800 account-books being of "any practical use" for the study. But this was judged in some respects to improve the worth of the survey as it identified the workers deserving of most interest. As the report stated: "The figures certainly show that the data supplied has come almost exclusively from those workers who are thrifty and careful, and on this account they may therefore be considered of special interest, as the community generally is mainly concerned in 'the struggle for existence' by those who practise economy in household and general expenditure." ${ }^{54}$ This was the political framing behind measuring the cost of living in the 1910s: to assess the lifestyles of the more 'virtuous' sections of the working class, rendering normative judgements into a 'scientific' model which would frame the public policy debate.

Despite its limited data set, normative framing and limited success in achieving its stated aim, the data gathered by the study was of assistance in determining weightings for early price indexes and was of considerable use for the Royal Commission on the Cost of Living of 1912, perhaps the zenith of New Zealand cost of living investigations in the pre-WWII era.

\footnotetext{
${ }^{52}$ Shaun Goldfinch, 2006, 'Shared State Experiments: Policy Transfer and Convergence in Australia and New Zealand', The Otemon Journal of Australian Studies, Vol. 32, p. 66

${ }^{53}$ J.W. Collins, 1912, Inquiry into the Cost of Living in New Zealand, Wellington: Government Printer

${ }^{54}$ Ibid.
} 


\subsection{THE ROYAL COMMISSION ON THE COST OF LIVING}

In the dying days of the Liberal administration a Royal Commission was convened to investigate causes of the rising cost of living and to make recommendations on how to resolve the problem. The scope of the commission was wide but their capacity for gathering historical data was limited to conducting interviews and the use of existing data sets. Aside from price lists and household accounts supplied by witnesses the only contemporary data available to the Commission was the 1912 Department of Labour study and a recently published doctoral thesis measuring historical wholesale price change. The first task of the commission was to define the 'cost of living', for this they cited standards defined in The Economics of Industry by prominent British economist Alfred Marshall. This was defined as "the sum of money that represents the efforts and sacrifices necessary to obtain the goods for securing and maintaining a certain amount of existence and efficiency." The Commission asserted that "Marshall's statement for England may be accepted with slight modifications for New Zealand". 55

With its limited data the Commission was able to establish that there had been a "tentative and only roughly approximate" sixteen percent increase over a fifteen year period coupled with a rise of 24 percent in wages over the same period. ${ }^{56}$ In attempting to determine causes, the Commission examined whether the increased costs had led to a higher standard of living using a variety of metrics including comparing household food expenditure in New Zealand to that in the United States and Europe with inconclusive results. The Commission also incited controversy by looking into possible price fixing, collusion and underweighted goods being supplied by retailers. Citing the orthodoxy among neoclassical economists of the time the principal problem was defined to be "the increasing supply of money, including gold and credit, and the increasing velocity of circulation". 57 The Commission noted widespread problems with merchant practices and monopolies and came down strongly against high tariffs supporting a policy of 'free trade'. The report also advocated New Zealand taking up representation on the proposed International Commission on the Cost of Living, which at the time was the pet project of prominent economist Irving Fisher. ${ }^{58}$

\footnotetext{
${ }^{55}$ Appendices to the Journals of the House of Representatives, 'Report of the Royal Commission on the Cost of Living', 1912, H-18, p. xi

56 'Report of the Royal Commission on the Cost of Living', p. xix

57 'Report of the Royal Commission on the Cost of Living', p. Ixxxvi

58 Irving Fisher, 1912, 'An International Commission on the Cost of Living', The American Economic Review, Vol.

2, No. 1, pp. 92-101
} 
The Royal Commission was strongly attacked by both merchants and populists with one newspaper describing its 'free trade' proposals as "an excellent thing for a small tribe of hook-nosed usurers". ${ }^{99}$ On its presentation to Parliament the report languished with little discussion of its contents. This was not only due to its controversial nature but also because the Liberal Government had been deposed since the Commission's formation and the new Prime Minister had little interest in advancing a political cause of his predecessor. Internationally, the report was praised for its robustness and for a short time New Zealand was seen as among world leaders in cost of living studies. John M. Keynes reviewed the report in The Economic Journal taking particular interest in the Commission's link "between education and the cost of living" in its proposal for greater education of economic fact and theory in schools. ${ }^{60}$ One American reviewer labelled the report "far superior to anything that has appeared in the subject thus far in the United States." ${ }^{\prime 1}$

The enduring legacy of the Royal Commission was its recommendation for a more robust system of national statistics concluding that "the first essential in the study of any social problem is correct diagnosis of the case". ${ }^{2}$ The list of recommendations included the creation of a department headed by a Government Statistician with full control and authority to collect and publish all state statistics. The Statistician would be sent abroad to locations such as the United States to study the most modern methodologies. An advisory board would be appointed comprised of representatives of different domestic interests to direct the course of statistical development. Yet it would not be until the post-WWII era that New Zealand statistics would resemble the vision of the Royal Commission and it was even later in 1975 that the Government Statistician would be given full independence and ultimate control over statistical methodology. But the Royal Commission did set a course that meant it would be the Government Statistician, rather than other government officials that would spearhead the development of New Zealand's national price index. Despite the lead role of the Government Statistician, as this thesis will show in a later chapter, even with enshrined

\footnotetext{
${ }^{59}$ New Zealand Truth, 1912, 'Cost of Living Commission. The Value of the recent report. Some Conclusions not justified. The disastrous policy of Freetrade.', September 7 1912, p. 1

60 J.M. Keynes, 1912, 'Review: The Course of Prices in New Zealand and Report of Commission on Cost of Living in New Zealand, together with Minutes of Proceedings and Evidence', The Economic Journal, Vol. 22, No. 88, pp. 595-598

${ }^{61}$ Warren Persons, 1913, 'Review: Report of Commission on Cost of Living in New Zealand, together with Minutes of Proceedings and Evidence', The American Economic Review, Vol. 3, No. 1, pp. 143-144

${ }^{62}$ Report of the Royal Commission on the Cost of Living', p. Ixxxvii
} 
'apolitical' independence established in law and expertise, the structure of the Price Index was still susceptible to political influence throughout its history.

\subsection{THE GOVERNMENT STATISTICIAN}

The creation of the position of Government Statistician in late 1910 was entirely the result of international influence. The British Empire had long attempted to coordinate an Imperial Census and in preparation for the 1911 census significant pressure was exerted across the colonies to standardise methods. ${ }^{63} \mathrm{New}$ Zealand was instructed to create a dedicated government bureaucrat to administer the census and other statistics akin to the Australian model. This was reflected in parliamentary debate about the position with the rationale more about duty and fealty to the Empire rather than direct benefit to New Zealand. ${ }^{64}$

While the powers granted in the 1910 legislation largely surrounded the conduct of the Census there were provisions included that directed the Government Statistician to collect statistics on a number of other topics including "Vital, social, and industrial matters". ${ }^{65}$ Although his powers steadily expanded, the Government Statistician did not have exclusive authority over statistics and often worked alongside other government departments and agencies. Aside from census directives the tasks of the Government Statistician were vaguely defined leaving a deal of interpretation to both the Minister and the official. As the focal point of statistical development in New Zealand, the predilections of the Government Statistician greatly affected the direction and focus of the CPI and official statistics particularly in their formative stages. Malcolm Fraser was appointed in early 1911 after the first appointee departed a few months into the job. Fraser was not a trained statistician, renowned more as a manager and administrator willing to take on and promote the ideas of others. ${ }^{66}$ While he was ably supported by skilled statisticians such as John Condliffe and Douglas Copland, it was Fraser's worldview that would shape the initial form of New Zealand's national price index.

As an indication of the wide scope of actions available to the Government Statisician, one of the first initiatives taken by his Office was the publication of J.W. Mcilraith's doctoral thesis. This significant work examined the course of

\footnotetext{
${ }^{63}$ A.J. Christopher, 2008, 'The quest for a census of the British Empire c.1840 - 1940', Journal of Historical Geography, Vol. 34, p.280

${ }^{64}$ Census and Statistics Act: First Reading, November 21 1910, New Zealand Parliamentary Debates (Hansard), vol. 153, p. 861

${ }^{65}$ Census and Statistics Act 1910, s21(b)

${ }^{66}$ George Wood, 1977, Progress in Official Statistics: 1840-1957: A Personal History, Wellington, Government Printer, p. 15
} 
wholesale prices in New Zealand from 1860 to 1910 applying contemporary price index theory to historical data. Considering that Mcllraith had little government support for his project the results were highly informative, forming the core of the historical price data used by the Royal Commission on the Cost of Living. Mcilraith had plans to continue his time-series, seeking to publish a set of annual price index figures in the official New Zealand Year Book. But this advance, (made before the Cost of Living Commission issued its report) was rebuffed by the Minister of Internal Affairs who felt that such statistics still remained under the purview of the Department of Labour. ${ }^{67}$

\subsection{THE BIRTH OF THE CPI}

Following the tabling of the Royal Commission report the Government Statistician was given authorisation to visit Australia to study the methods employed in the state and Commonwealth Statistics offices. Fraser returned to New Zealand in June 1913 and reported his findings to the Minister of Internal Affairs, having high praise for the place of statistics in political and economic decision making as well as the practical methods of tabulation and collection. The Government Statistician found State and Commonwealth officials to be very supportive in advising on the development of New Zealand statistics and Fraser urged his government to improve local statistics by adopting Australian methods. ${ }^{68}$ Particularly intrigued with the Commonwealth Statistician's investigation of industrial and economic circumstances including retail prices and the cost of living, Fraser recommended to parliament that his office (assisted by the Department of Labour) be given authorisation and resources to undertake industrial and economic inquiries "on similar lines to those instituted by the Commonwealth Statistician". ${ }^{69}$ With the request granted Fraser set about his inquiry in earnest in early 1914.

The purpose of the investigation was two-fold, to establish a system for the regular collection of commodity prices for a regularly published index and also to establish the course of price change since the commencement of the social and economic reforms in the 1890s. For these tasks the Government Statistician relied heavily on the expertise of the Australian Commonwealth and State statisticians. Fraser had been previously been supplied by Knibbs with much of the explanatory literature and material used in creating the Australian index. As work on the project

\footnotetext{
${ }^{67}$ Letter, George Russell, Minister of Internal Affairs, to Minister of Labour, George Laurenson, 1 July 1912, in STATS Series 1, Record 22/1/7, Archives New Zealand

${ }^{68}$ Malcolm Fraser, 1914, 'Report of the Government Statistician on Visit to Statistical Offices of the Commonwealth of Australia and Australian States', AJHR, 1914, H-12, p.1

${ }^{69}$ Fraser, 1914, 'Report of the Government Statistician on Visit to Statistical Offices of the Commonwealth of Australia and Australian States', pp. 4-5
} 
progressed Fraser regularly communicated with Australian statisticians updating them on his progress and soliciting advice on specific technical issues. ${ }^{70}$

The onset of the Great War hampered the development of the index initially as government resources were redirected towards the war effort. But as the economic effects of the war became apparent with prices increasing for many imported goods, the perceived need for the development of a retail price index became even more pressing. Fraser thus integrated a third task into the study, establishing the effects of wartime on the cost of living. After many delays, the first results of the Cost of Living inquiry were published in mid-1915 with a more through report published at end of that year. Although Fraser had planned to investigate wholesale and import/export prices these investigations were dropped because of the pressures of war and the greater need for cost of living data for what was named the Retail Price Index (RPI). The methodology used to calculate the index was drawn from Australia with Fraser using Knibbs' Laspeyres-based 'aggregate-expenditure' method. Weightings were largely based upon the 1910 Department of Labour cost of living survey. There were two principal reasons for adopting the Australian methodology; Fraser was convinced that Knibbs's method was the "best and most accurate" measure of price change while also being simple to calculate, citing contemporary international research on price indexes to support his claim. ${ }^{71}$ Secondly, Fraser believed that great use could be made of the 'comparative experience' of the two dominions, writing in a letter to Knibbs that "I sincerely hope that the methods and work of the two offices will come more and more into line in future, and I would like to do all in my power to forward uniformity". ${ }^{72}$

The choice of commodities to measure price change in was derived from the Australian index; thus the RPI had four groups in its regimen: groceries, dairy produce, meat and house rent. This meant the New Zealand index excluded clothing, as it was argued that the role of clothing as a luxury item meant it was volatile to price change due to fashion trends and therefore unsuitable for measuring change in the cost of living. Fraser, like Knibbs, also incorporated an examination of the differing rates of price change in major towns and cities and assessed relative 'purchasing power'. While the RPI was incomplete as a measure

\footnotetext{
${ }^{70}$ For example: Letter, Malcolm Fraser, Government Statistician to Victorian State Statistician, A.M. Laughton, 24 July 1914, in STATS Series 1, Record 22/1/7, Archives New Zealand

${ }^{71}$ Malcolm Fraser, 1915, Report on the Cost of Living in New Zealand 1891-1914, Wellington, Government Printer, p. 5

${ }^{72}$ Letter, Malcolm Fraser, Government Statistician to Commonwealth Statistician, George Knibbs, 24 June 1915, in STATS Series 1, Record 22/1/7, Archives New Zealand
} 
of consumer price change, the creation of a systemic method of collection and collation of price change was important for the integration of price indexes into economic and political decision-making. Aside from a period during WWII, a price index of retail commodities has been regularly published in New Zealand since 1915.

Concurrent with the publication of the RPI the powers of the Government Statistician were strengthened which gave Fraser greater scope to develop New Zealand's statistical framework. But the activities of war, where Fraser had responsibilities for conscription meant little development occurred beyond the establishment of the basic RPI. While Australia was the most important international influence upon on the form of New Zealand's RPI and official statistics at this time, shortly after the war there was an attempt to impose uniformity of statistical methods across the British Empire. Stemming from the efforts to standardise census-taking there had been discussions on increasing the compatibility of official statistics across the Empire to improve commerce and trade. At the Imperial Conference of 1917 it was resolved that a Statistical Conference of Empire Statisticians would be held in 1920 to attempt to coordinate methods. The conference was based upon the contemporary model of Australian statistical conferences that co-ordinated State and Commonwealth statistical efforts. The conference had two broad purposes: the establishment of an imperial statistics office that would supervise statistics across the Empire and to enhance statistical techniques throughout the Empire through the exchange of ideas. $^{73}$

On Fraser's journey to the British-based Conference the Government Statistician took the opportunity to observe processes within statistical offices in Australia, South Africa, Canada, the United States as well as the United Kingdom. Fraser was impressed with the technology used in the offices and noted that the process of statistical centralisation which had just begun in New Zealand was well underway overseas. In his report on these visits Fraser urged his government to make greater use of technology and hasten the centralisation process, although neither recommendation was ultimately followed to the extent that Fraser wished. ${ }^{74}$

\footnotetext{
73 Jean-Pierre Beaud and Jean-Guy Prévost, 2005, 'Statistics as the Science of Government: The Stillborn British Empire Statistical Bureau, 1918-20', The Journal of Imperial and Commonwealth History, Vol. 33, No. 3, September 2005, pp. 371-372

${ }^{74}$ Malcolm Fraser, 1920, 'Report of Government Statistician on British Empire Statistical Conference', AJHR, 1920, H-12, pp. 1-2
} 
At the Conference Fraser found himself aligned with statisticians from other Dominions against British officials who were perceived to be attempting to dominate proceedings. Dominion Statisticians felt that the British attitude towards them was overly paternalistic possibly reflecting the maturing independence of the young nations and the similarity of their own statistical development. ${ }^{75}$ After negotiations that were occasionally fractious, the mandate and charter of an Empire Statistical Bureau that would act as a "clearing house" for statistics was agreed upon. The planned Bureau would operate as an Empire representative in dealings with the newly created International Labour Organisation (ILO) which included statistics as part of its mandate. ${ }^{76}$

Many resolutions on the structure of price indexes were agreed upon, these included adopting the aggregate-expenditure method (as used in Australia and New Zealand at the time), open disclosure of methodology and prices, regular revisions and monthly publication of a retail index of 'staple commodities'. Although on his return Fraser attempted to set about standardising the index and other statistics to Empire specifications, over time the resolutions had little long-term effect on the structure of New Zealand's RPI. For example, in 1930 New Zealand disregarded Imperial recommendations by using a method other than 'aggregate-expenditure' for the calculation of groups and sub-groups of items within the RPI.

The New Zealand government was instrumental in stymieing the grand plans for the Empire Statistics Bureau. While Fraser argued strongly in favour of the creation of the Bureau, the estimated annual cost to New Zealand of 1000 pounds (of an estimated $f, 30,000$ total) was seen as excessive for the government of the day given economic conditions. New Zealand's decision to opt out prompted the Australian government to express its hesitation at the plan which ultimately torpedoed the idea. ${ }^{77}$ During the 1920 s efforts at Empire standardisation continued but soon fell away during the Great Depression and by the time of the next Empire Statistics Conference in 1935, the idea had quietly disappeared from the agenda. ${ }^{78}$ After WWII Empire conferences continued in the form of meetings of Commonwealth Statisticians in which New Zealand actively participated. But the relevance of the Commonwealth in determining the form of the CPI and

\footnotetext{
${ }^{75}$ Beaud and Prévost, 'Statistics as the Science of Government', pp. 386-387

${ }^{76}$ British Empire Statistical Conference, 1920, Report and Resolutions adopted by the First Conference of Government Officers engaged in dealing with Statistics in the British Empire (with four appendices), London, H.M. Stationery Office, pp. 31-32

${ }^{77}$ Beaud and Prévost, 'Statistics as the Science of Government', p. 385

${ }^{78}$ Beaud and Prévost, 'Statistics as the Science of Government', p. 372
} 
official statistics in New Zealand was consultative, developmental and informative rather than a standard setting role.

From its early development until the 1920s, New Zealand was largely passive in determining the underlying rationale and methodology of its national price index. Ideas 'copied and pasted' from the British Empire strongly influenced the design of the institutions such as the Statistics Office and the Department of Labour that developed the New Zealand's first price index. But practical and direct contact with Australian statistical authorities often superseded Imperial influence.

Methods for measuring price change were largely lifted from Australian institutions who themselves had borrowed (and in some cases improved upon) methodologies from Europe, the UK and the United States. There were some important political differences in New Zealand's measurement of the 'cost of living' compared to elsewhere, particularly around the idea of the 'worthy poor'. But as the price index began to take on greater political and economic importance in the inter-war period, it gradually morphed from being a tool of social discovery to being a macroeconomic tool of redistribution. Thus the index became a site of political struggle as powerful domestic interests and institutions began to assert greater influence on the composition of the statistic.

\subsection{THE COURT OF ARBITRATION}

The index took on greater importance in economic management through the interwar period principally through its use by the Court of Arbitration to determine wage rates. The primacy of the index in determining wages meant the needs of the Court and the interests of employers and unions took on greater precedence in the composition of the index. While New Zealand did not spurn efforts at global standardisation during this period, it was not a 'fast follower' and on occasion international requirements disguised changes to the index that were driven by domestic concerns. Further development of the RPI was largely curtailed by the Great Depression although price controls and the renewal of Arbitration Court powers enacted by the 1935 Labour Government refocused attention on statistics to evaluate policy outcomes. The constraints of the Second World War necessitated a remodelling of the index which became tightly integrated into wartime economic stabilisation policies.

The Court of Arbitration was created as part of the labour reforms of the 1890s as a mechanism to resolve employment disputes and avoid the 'labour problems' of the 'old world'. But over time the Court evolved into being a wage setting device for much of New Zealand's workforce and it soon integrated 'Cost of Living' 
adjustments into its judgements. Since its inception the Court had followed 'fair wage' principles, determining wage rates based on what was being paid by reputable employers and applying this to employers generally. ${ }^{79}$ But gradually its determinations came to incorporate the idea of a 'living wage' based on the idea of maintenance of a certain standard of living for workers. This system of compulsory arbitration was unique to Australasia, so it was unsurprising that the New Zealand court would look towards Australia for direction and influence in its judgments. The concept of a 'living wage' first appeared in the 1907 Harvester judgment in the Australian Court where Judge H.B. Higgins ruled that an employer must pay his employees a wage which guaranteed the standard of living of "a human being in a civilised community". ${ }^{80}$ This precedent was followed in subsequent Australian Court judgements and the idea of a 'living wage' soon began to appear in New Zealand determinations. ${ }^{81}$

The New Zealand Court began to actively use the RPI to aid its judgments during the Great War. Because of the economic effects of its decisions on employers and workers, the Court became the most important user of the index which became a site of contention in employment relations. Perceived inaccuracies or perceived bias in the index were regularly used to dispute Court decisions from both sides. Employers often argued that use of the RPI did not take into account the profitability of a particular industry or account for business cycles. Unions argued that use of the RPI to keep pace with the cost of living did not allow workers to improve their standard of living, keeping them 'locked in' at the living standards of 1914 (the base of the index). ${ }^{82}$

\subsection{THE 1920 'ERROR': POLITICS CHANGES THE INDEX}

Attacks against the RPI were seen as attacks on the integrity of the Court and a 1920 judgement based on incorrect RPI data had significant consequences for the development of the index. At the time the Court had made half-yearly decisions on wage adjustments based on a six-monthly moving average of the RPI. But one particular judgment used monthly data which awarded workers a far greater wage increase than otherwise warranted. The mistake was soon identified and in response to the controversy the Court requested that the Statistics Office compile

\footnotetext{
${ }^{79}$ Noel S. Woods, 1963, Industrial Conciliation and Arbitration in New Zealand, Wellington, Government Printer, p. 95

${ }^{80}$ H. Heaton, 1921, 'The Basic Wage Principle in Australian Wages Regulation', The Economic Journal, Vol. 31 , No. 123, p. 310

${ }^{81}$ Woods, Industrial Conciliation and Arbitration in New Zealand, p. 96

${ }^{82}$ Woods, Industrial Conciliation and Arbitration in New Zealand, p. 107
} 
a more comprehensive RPI with a greater range of commodities. ${ }^{83}$ The Office had begun to collect prices of clothing and miscellaneous commodities in the previous year and this may have contributed to the error. Price movement in the clothing group index was calculated by the Office whereas the Court calculated price change in this group using its own method. ${ }^{84}$ The Office commenced the compilation of an 'all-groups' index in 1921 for the exclusive use of the Court which covered $87.5 \%$ of 1911 budget survey consumption rather than the previous $60 \%{ }^{85}$

While clothing was now included in the index the specific choices of commodities were odd. Items in the regimen were based on what a family would 'ordinarily wear'. While men were deemed to have ready-made clothes, price change in women's clothing was measured on the price of materials only. This was arguably a way of avoiding the problem of changing fashions and simplifying the measurement of price change. It appears that much of the chosen clothing and miscellaneous items were drawn from a UK Board of Trade study. ${ }^{86}$ A change from making six monthly to three-yearly wage awards at the end of 1923 resulted in the Statistics Office being granted permission from the Court to publish the 'allgroups' index. This became the new revised RPI although the public justifications for the change were curious.

The 1920 Statistics Office Report on Prices detailed new wholesale and export/producer indexes as well as restating the methodology behind the RPI. Techniques for collecting house rent data became more closely aligned with Australian methods. In reasoning for continuing to exclude clothing from the index the Government Statistician cited "Australian, Canadian and South African statistical authorities" as approving of this decision. ${ }^{87}$ Yet when the all-groups RPI was made the official index in 1924, the Government Statistician cited the same authorities and the requirements of Empire standardisation to justify the inclusion of clothing and miscellaneous items. While both statements are arguably correct in that other Dominions had largely compiled 'all-groups' indexes since the 1920

\footnotetext{
${ }^{83}$ Wood, Progress in official statistics, p. 88

${ }^{84}$ Letter, Malcolm Fraser, Government Statistician to Professor of Economics, Canterbury College, Albert Tocker, 30 May 1923, in STATS Series 1, Record 22/1/32, Archives New Zealand

${ }^{85}$ Wood, 1977, p. 90

${ }^{86}$ In 1915 Fraser was forwarded details of the items used in the 'clothing' and 'miscellaneous' groups of a British investigation: Letter, G.S. Barnes, Department of Labour, British Board of Trade to Government Statistician, Malcolm Fraser, 25 April 1913, in STATS Series 1, Record 22/1/5, Archives New Zealand

${ }^{87}$ Malcolm Fraser, 1920, Prices: An Inquiry into Prices in New Zealand. 1891-1919, Wellington, Government Printer, p. 13
} 
Empire Conference, it disguised that the real reason for change had been the requirements of the Court of Arbitration.

\subsection{CHANGING INTERNATIONAL POLITICAL INFLUENCE}

Efforts towards integrating official New Zealand statistics into the international system continued throughout the 1920s. In 1924 Fraser resumed regular New Zealand attendance at the Australian Commonwealth and State Statisticians Conference. ${ }^{88}$ On the other hand an invitation to the $192817^{\text {th }}$ Congress of the International Statistical Institute was declined. ${ }^{89}$ In 1929 the Government Statistician reported on New Zealand efforts at achieving statistical Empire uniformity. Fraser noted that the results had been more noticeable among the Dominions rather than between the UK and the Empire due to the lack of a centralised British statistical agency. ${ }^{90}$ This was the last mention of Empire standardisation by the Government Statistician in an Annual Report to Parliament. The economic recession of the 1930s followed by WWII ultimately ended the Empire standardisation project. At this time a new international organisation in the form of the ILO began to take primacy in setting international statistical standards.

The ILO was created concurrently with the League of Nations with an operational creed that "universal and lasting peace can be established only if it is based upon social justice". ${ }^{11}$ In the early years of the organisation it was found that much of the statistical data required to advance its cause was inadequate. Thus the ILO Bureau of Statistics was created to devise guidelines for the comparable measurement of labour statistics including wages, occupations, industrial disputes and consumer prices. ${ }^{92}$ The inaugural International Conference of Labour Statisticians (ICLS) was held in 1923 and in 1925 the Conference set out the first criteria and guidelines for retail price indexes. Among the resolutions agreed upon, an 'all-groups' index was codified as an international standard, members were invited to conduct new budget studies and 1930 was agreed upon as the future base year for each government's index. ${ }^{93}$

\footnotetext{
${ }^{88}$ Appendices to the Journals of the House of Representatives, 1924, 'Report of the Government Statistician', H22, p. 10

${ }^{89}$ Appendices to the Journals of the House of Representatives, 1928, A-1, p. 10

${ }^{90}$ Appendices to the Journals of the House of Representatives, 1929, 'Report of the Government Statistician', H22 , p. 9

${ }^{91}$ International Labour Organisation, 'Constitution of the International Labour Organisation', http://www.ilo.org/dyn/normlex/en/f?p=1000:62:0::NO:62:P62 LIST ENTRIE ID:2453907:NO

92 ILO Bureau of Statistics, 2008, 'ILO statistical standards: 85 years of setting international guidelines for labour statistics', Bulletin of Labour Statistics, 2008-1, p. IX

${ }^{93}$ International Labour Office, 1925, The Second International Conference of Labour Statisticians, Studies and Reports Series N (Statistics) No. 8, ILO, Geneva, pp. 69-70
} 
Although New Zealand was a founder member of the ILO this did not reflect a special connection to the organisation. The British had signed up the Empire as a whole to the ILO in 1919 and there was some confusion initially as to whether New Zealand was actually a member. ${ }^{94}$ Through the 1920 s the New Zealand government was largely disinterested in the organisation, declining to send representation to any ILO conference. By the end of the decade New Zealand was one of only three members to have not sent a delegation to an ILO meeting. ${ }^{95}$ While New Zealand did attend the 1930 Conference, it was not until 1938 that the then-Labour Government would ratify ILO conventions. ${ }^{96}$ Yet while New Zealand was kept its distance from ILO Conferences and conventions during the inter-war period there was some interest in the research activities of the organisation. ILCS and other international standards were keenly followed in the Statistics Office during the 1920s with myriad conventions on health, population, trade and economic statistics implemented. ${ }^{97}$

This standardisation process extended to the RPI; in accordance with the 1925 ICLS resolution, the Government Statistician conducted a new budget study and revised the index using 1930 as a base year. This revision signified a drift away from the Australian and Empire principles towards those of the ICLS. For example while the 'aggregate expenditure' calculation method derived from Australia was retained for the food and fuel groups, the 'geometric means' method from the ICLS was employed in the clothing and footwear sub-groups. ${ }^{98}$ The New Zealand index also incorporated new items such as fresh fish that remained excluded from the Australian iteration. During the 1930s, publication of actual price quotations for many items was discontinued contravening the Empire standard that data used in compilation of the RPI should be published. ${ }^{99}$

\subsection{DEPRESSION, REJUVENATION, POLITICS AND WAR}

The economic depression of the 1930s and subsequent reduction in funding to the Statistics Office curtailed much statistical development and the 1930 revision to the RPI was to be the last before WWII. The election of the Labour government

\footnotetext{
${ }^{94}$ Nigel Haworth and Steve Hughes, 2009, 'A Distant Detachment: New Zealand and the ILO 1919-1945', Paper presented at 90 years of the ILO: the significance for Australia and New Zealand, Auckland, November 2009, pp. 1-2 
in 1935 brought with it a new economic paradigm with the implementation of a 'Guaranteed Price' scheme, greater trade unionism and the bedding in of the 'welfare state'. The new government also amended the Industrial Conciliation and Arbitration Act mandating that the basic wage for adult males was to be fixed at such a rate so as to, in the opinion of the Court of Arbitration, be sufficient to "enable an man in receipt thereof to maintain a wife and three children in a fair and reasonable standard of comfort". 100

To aid in its plans the Government created a Social Science Research Bureau within the Department of Science and Industrial Research (DSIR) to investigate social and economic conditions. The first study conducted by the Bureau was an enquiry into the standard of living of dairy farmers which was then followed by an investigation into the living conditions of urban workers. The Bureau was supported by Carnegie Corporation which funded the services of an American professor of Rural Sociology to advise on international best practice and methodology. ${ }^{101}$ The results of the study into urban workers, completed in 1939, found that despite reversals of depression-era salary cuts and the implementation of price controls, living conditions generally remained poor among those surveyed. The results however did not sit well with the rhetoric of the Government at the time and the report was suppressed which prompted the head of the Bureau to quit in disgust. ${ }^{102}$ With the onset of WWII the Bureau was disbanded although the findings of the urban workers report would be later used in the wartime refashioning of the RPI into the Wartime Price Index.

To maintain stability in wartime conditions an economic stabilisation plan was enacted by the New Zealand Government. Central to the plan was the creation of the Wartime Prices index (WPI) which was used as a check on both statecontrolled prices and wages. The index replaced the RPI which had become unsuitable for austerity conditions (although data collection continued throughout the war so as to preserve continuity). The index was devised by a committee representing interests including unions and employers, however the Government Statistician was not included in the group. Weights were based on an approximation of the 1942 'family standard of living' utilising the 1930 budget study and the 1939 DSIR study. The regimen of the index reflected wartime austerity, although in a change from the RPI group weightings were not intended to reflect a 'working class' standard of living. The index utilised aggregate

\footnotetext{
${ }^{100}$ The Industrial Conciliation and Arbitration Amendment Act 1936

${ }^{101}$ AJHR, 1937, 'Report of Social Science Research Bureau', H-34, p. 40

${ }^{102}$ Wood, Progress in official statistics, p. 78
} 
expenditure for almost all groups and sub-groups and fresh fruit and vegetables were included for the first time. The output of the index was also directly linked to the wage awards of the Court of Arbitration, although this mechanism was not activated during the war. The WPI was almost entirely the product of the domestic considerations of domestic institutions with little consideration for international comparability. For example, Australia, although it had also implemented economic controls, did not create a special index, instead making modifications to its RPI.

\subsection{CREATING AN 'OBJECTIVE’ CPI}

Post-war New Zealand was a different place, socially and economically to the nation that had entered the war in 1939. For example, New Zealanders were increasingly likely to live in urban areas and employed in technologically sophisticated industries. Neither the RPI with its 1930 basis nor the austerity of the WPI were adequate measures of price change. But the outcome of the war had also remade the world economy. The UK was no longer a great power and the Western economy was now directed by the United States through the Bretton Woods system. The new economy of the 'free world' was a compromise between the unrestricted international economic liberalism pre-1914 and the domesticallyfocused protectionism of the 1930s. States co-operated using international institutions to facilitate market integration and preserve economic stability while retaining sufficient autonomy to pursue domestic agendas such as full employment and strong welfare systems. ${ }^{103}$

A keen participant in the new internationalism of the post-war era and a founding member of the United Nations, New Zealand was eager to demonstrate its evolving sense of nationhood on the international stage. This attitude was reflected in international statistical development, with active New Zealand participation in the ICLS and the newly created United Nations Statistical Commission (UNSC). But these engagements also brought about new requirements that local statistics be compatible with new international frameworks and standards. Concurrently domestic considerations determined what information would be collected and what statistics would be produced. In many respects the development of New Zealand's CPI in the post-WWII era reflected the Bretton Woods system. Domestic interests and institutions shaped the statistic within the bounds of internationally determined norms and standards.

\footnotetext{
${ }^{103}$ John Ruggie, 1982, 'International regimes, transactions, and change: embedded liberalism in the postwar economic order', International Organization, Vol. 36, pp. 379-415
} 
George Wood, the then Government Statistician, was essential to New Zealand's post-war statistical internationalism, ensuring that the post-war CPI met international standards. Worldly and knowledgeable in statistical methods Wood had been part of the Statistics Department since the 1920s. During WWII he had worked in the Palestine Statistics Office and after retiring as Government Statistician in 1958 he became chair of the UNSC. The WPI stayed in place in the immediate post-war years and the Government Statistician faced considerable pressure from domestic interests to revise the index to more accurately reflect post-war conditions. Organised labour agitated for 'modernisation' of the index as they believed the wartime austerity of the WPI would make it difficult for wageearners to improve their standard of living. ${ }^{104}$ But in a letter written to his controlling Minister in July 1947, Wood requested that New Zealand follow the lead of the UK and delay revising the index until after the 1947 ILCS Conference. $^{105}$

The premise of the ICLS Conference was "to improve science for the greater wellbeing of mankind" and it incorporated emerging influences on international statistics including representatives from the United Nations, the International Monetary Fund and the Food and Agricultural Organisation. ${ }^{106}$ The Conference signified the end of passive New Zealand acceptance of international price index standards. While not always greatly influential, New Zealand was now an active participant in determining price index norms. New Zealand's delegation to the Conference consisted of Wood and Jack Baker (then of the Labour Department and future Government Statistician), which was greater than many other nations including Australia that sent a single delegate. Wood was an active participant in the committee that devised the resolutions on measuring price change, which although not comprehensive, set out broad guidelines on the purpose, basic methodology and even acceptable nomenclature of price indexes. ${ }^{107}$

But at the same time the resolutions were not overly prescriptive, allowing wide scope for satisfying domestic needs. For example, choices were made between measuring pre-war or post-war consumption patterns and which groups of society to encompass. The choice to measure "the post war consumption of the generality

\footnotetext{
${ }^{104}$ Wood, Progress in official statistics, p. 79

105 Letter, Government Statistician to Minister in charge of Census and Statistics, 18 July 1947, in STATS Series 1, Record 22/1/71, Archives New Zealand

${ }^{106}$ International Labour Office, 1948, The Sixth International Conference of Labour Statisticians: Montreal, 4 to 12 August 1947, Studies and Reports New Series No. 7 (part 4), ILO, Geneva

107 International Labour Office, 1948, pp. 60-62
} 
of New Zealand consumers" perhaps represents the (actual and imagined) egalitarian ethos of the society at the time. ${ }^{108}$

In 1948 a committee was organised to formally determine the nature of the postwar index, although this masked the fact that Wood and his officials had largely completed an underlying framework for the new index based on ICLS resolutions before the committee had even begun sitting. ${ }^{109}$ These committees, convened every few years from 1948 up until the present day, now known as the 'Revision Advisory Committee' are the formal arena for political discussion, conflict among invited actors with a high level of interest in the framework of the CPI.

The resulting index, formalised in 1949, represented a significant departure from the design of the previous indexes. The idea of reflecting austerity or a "working class' standard of living in the index was abandoned with it now designed to represent $95 \%$ of 'normal' household consumption. As such the number of items included in the regimen was greatly expanded and in a significant change, owner occupied housing was included in the index for the first time. Many countries did not include house ownership in their indexes at this time but New Zealand's relatively high rate of owner-occupied homes, as well as the support of both unions and employers, justified the change to the Review Committee. ${ }^{110}$ The index returned to the 'aggregate expenditure' method of weighting for all groups and continued the innovation of the WPI by including fresh fruit and vegetables. In accordance with ICLS recommendations the Department of Statistics was given its own cadre of staff to collect prices meaning they would no longer rely on the Labour Department for field work. But perhaps the most noticeable change to the lay-person was the renaming of the index to the 'Consumers' Price Index'. The name change was an attempt to reinforce the idea that the index was no longer a measure of the 'cost of living' but an objective measure of the 'cost of stuff. The index was subsequently formalised in the regulations governing the Court of Arbitration which was required in its wage determinations to account for any "rise and fall in retail prices by any index published by the Government Statistician." "111

But the design of the new CPI was not as 'objective' as it claimed to be. For example, the continued exclusion of alcohol from the index was the result of direct political interference. While the report of the Committee cited the exclusion of

\footnotetext{
${ }^{108}$ Wood, Progress in official statistics,, pp.96-97

${ }^{109}$ Wood, Progress in official statistics,, p. 95

${ }^{110}$ AJHR, 1948, 'Report of Index Committee, 1948', H-48, pp. 18-19

${ }^{111}$ Brian Easton, 'A Political Economy of the Consumers Price Index' in Sharleen Forbes, and Antong Victorio (eds), 2014, The New Zealand CPI at 100: History and Interpretation, Wellington: Victoria University Press, p.124
} 
alcohol from the price indexes of the United States and the former Dominions to justify its exclusion, it was actually due to the intervention of the then New Zealand Prime Minister, Peter Fraser. The PM had a puritanical view on the role of alcohol in society and did not want beer included in the CPI regimen as that could result in workers' wages being increased to compensate for alcohol price rises. Although the exclusion of beer was odd for an index that was claimed to not omit commodities that were "regarded as non-essential or socially undesirable", this was remedied in the 1955 revision after the PM had left office. ${ }^{112}$ While Fraser's direct interference with the index structure may appear crude by contemporary standards, there are parallels with the subtle removal of price changes in tobacco from the version of the CPI currently used for benefit indexation in New Zealand.

The post-war CPI symbolised the shifting dynamics of New Zealand in the postwar and post-colonial world. It signalled a drift away from colonial ties to Australia and the UK towards more active engagement with the international community led by the United States. While standards for price index development were set externally; it was ultimately domestic politics, including technocratic decision-making, power struggles between labour and capital and overtly political interventions that determined the exact form of the price index and the effect it would have on the economy.

\subsection{HOW POLITICS CHANGED THE INDEX}

This case study has shown how politics changes technology. The CPI was originally conceived as a prescriptive tool of social discovery during the First World War to ascertain the cost of living for a working family, yet by the conclusion of the Second World War, the index had been transformed into an objective tool of economic redistribution. This occurred because the primary function of the index, evolved from being to investigate the 'cost of living' and inform social policy, to primarily being a mechanism to determine change in wages via the Court of Arbitration. Thus the political weight of the Court and the interest groups invested in its determinations assumed greater over the form of the index than the original groupings that first devised the index. Internationally too, the political interests that set the economic and social boundaries for New Zealand as a state changed, from being a Dominion heavily influenced by the British Empire in the early 1900s, by 1949 the international influences on New Zealand were tilted

${ }^{112}$ Wood, Progress in official statistics, p. 96 
more towards the United States and a new world order transmitted through international organisations such as the United Nations and the ILO.

Almost all of the technology and protocols present in the 'improved' CPI introduced in 1949 had been developed well before the commencement of the Second World War, so it was not technological improvement as a matter of course that changed the index, it was the politics surrounding it that altered the form of the index. The post-war change to the international political context did not mean changes to the index were a fait-accompli among all developed countries either. For example, Australia, which the New Zealand index was partially based upon in its formative years, was similarly impacted by the war and yet because of differences in domestic politics, a corresponding change in the Australian CPI did not occur until $1960 .{ }^{113}$

The greater power held by the Court of Arbitration and unions following the Great Depression, the election of the first Labour Government in 1935 and the Second World War meant they held greater veto power over the form of the index. This significant change to the index was the result of a consensus between the Court of Arbitration, the technocrats of the Statistics Office, unions and employer groups that broadly agreed to 'modernisation' of the index would improve outcomes for their interests. This occurred within an international context that permitted and arguably encouraged this significant change.

\subsection{INFORMING INSTITUTIONAL CHANGE THEORY}

The development and change in the CPI over the first half of the $20^{\text {th }}$ Century is pertinent to theories of institutional change. This episode of change in the CPI exemplifies aspects of both the path dependence-punctuated equilibrium and the gradual-incremental change arguments.

There appears to be strong evidence in favour of path-dependence. The choice of the Statistics Office as the principal technical determinant and 'gate-keeper' of the index rather than the more 'activist' Department of Labour combined with the creation of a Court of Arbitration that used the CPI to determine wages were the antecedent conditions that constrained and shaped change to the index. Aside from the 1920 'error' with the index which prompted a revision to its methodology, changes to the index over its early history largely coincided with exogenous shocks, marked by significant price inflation, often caused by war or

\footnotetext{
${ }^{113}$ Australian Bureau of Statistics, 2005, 'History of retail/consumer price indexes in Australia' in Year Book Australia 2005
} 
economic crisis. In this case, the economic and political conditions brought about by the outcome of the Second World War was the critical juncture that formalised permanent change to the index as an objective positivist measure of price change.

The critical juncture of the aftermath of the war, rebalanced the post-war global system towards 'embedded liberalism' in part due to the ascendance of American power and the receding power of Europe. The technocratic role of the Statistics Office and the needs of the Court of Arbitration and its surrounding interest groups entrenched the function of the CPI in New Zealand's economy based on the antecedent choices made during the First World War to put these institutions and interests in control of the index.

Alternatively, what may appear to be an example of path dependence and change caused by exogenous shock may instead have been an example of gradual incremental change that occurred largely endogenously through continuous struggle among influential actors. The path dependence argument in part relies on the role of the Court of Arbitration and its use of the index being largely stable since its beginnings, but that was not the case. The institution of the Court itself, and its role in wage setting was the site of on-going power struggles throughout its existence and the original decisions that created at the turn of the century by no means determined with finality its role in economic redistribution. For periods of time, particularly through the late 1920s and early 1930s the Court was largely neutered, subsequently minimising the relevance of the index in wage determination. ${ }^{114}$

The ambiguities in the structure and use of the index were continuously fought over by actors in continual struggle for the prevalence of the status quo or change. While the shock from the aftermath of war undoubtedly forms of part of the explanation for change in the institution of the CPI, the effect of WWII was indirect. The period of war temporarily quelled the power struggles between capital and labour for, which were renewed anew at its conclusion. The events after the war presented new opportunities for change actors to exploit ambiguities in the index which had existed to the side on hold argument suggests that the 1949 change to the CPI, while 'inevitable', had merely been delayed through institutional stability and inertia and that only the 'shock' of the event of the war prompted its occurrence.

It may be that the layering the economic mechanism of wage determination upon the original function of the index as a tool of social discovery ultimately changed

${ }^{114}$ Woods, Industrial conciliation and arbitration in New Zealand, Chapter 4 
the form of the index from a subjective to objective measure. Layering contends that new functions are added to institutions alongside existing purposes that introduce new actors that bring about change. But the social discovery aspect of the early price index was largely vanquished by 1949. The conversion approach is more salient to this story of institutional change as it was the institution of the CPI itself that adjusted to meet the needs of the new paradigm. This first occurred in 1920 after the 'error' in the index caused a wage determination to be rescinded. The index was then converted into a form that suited its chief political user. The redirection of the CPI's purpose created further political struggle in what the function of the institution should be. This led to compromise among actors and interests following WWII to mitigate ambiguities in the enforcement and interpretation of its rules. 
CHAPTER 4: THE 'BRAVE NEW WORLD': THE CPI AND THE POLITICS OF NEO-LIBERALISM

\subsection{SUMMARY}

In 1975, on a unanimous vote, Parliament passed a revised Statistics Act which enshrined independence for the Government Statistician. The legislation specified that "The Statistician shall have the sole responsibility for deciding the procedures and methods employed in the provision of any statistics produced or to be produced by the Statistician." 115 Independence of the Government Statistician had been an observed convention for many years, and a code had been in place among Ministers from the early $1960 \mathrm{~s}^{116}$ this legislative change was explicit in signalling that the political interference in the structure of official statistics including the CPI was prohibited. While crude interference in the measurement of household inflation, such as that of Peter Fraser in 1949, was now officially forbidden, technology in the form of the CPI was still subject to change as a result of politics. This is because, as was also officially codified in the Statistics Act, official statistics were to be fit for purpose and consultation among interested parties was legally required to be undertaken by the Government Statistician. ${ }^{117}$

This chapter will demonstrate that despite the stated political neutrality of official statistics, the CPI changed in the late-1990s as a consequence of political struggle. The case study will show that after the CPI became an instrument of monetary policy because of the political choice to implement inflation-targeting, the index itself changed through the removal of interest rates from the official regimen of the index. Although direct political interference in the structure of the index was illegal, by changing or adding to the functions of the index through political struggle, which supplanted powerful users of the index in favour of others, the form of the statistic itself ultimately changed.

This chapter will further inform theories of institutional change by examining a case study of which there is no immediately apparent exogenous shock that caused the removal of the measurement of price change in interest rates from the CPI regimen in 1999. Yet this case study could be an example of path dependence due to antecedent political decisions to implement inflation targeting as monetary policy a decade prior. But this significant change to the price index is also arguably

\footnotetext{
${ }^{115}$ The Statistics Act 1975, section 15

${ }^{116}$ Hansard, 'Second Reading Debate on the Statistics Bill', March 261975

${ }^{117}$ The Statistics Act 1975, section 10
} 
an example of gradual incremental change through shifts in political power and context.

\section{2 ‘STAGFLATION’ AND THE RISE OF NEO-LIBERALISM}

While the reasons for New Zealand's economic decline in the 1970s are often disputed, there is agreement among most historians that the decade was a turning point in New Zealand's economic history. The post-war period from 1945 to 1973 in New Zealand saw prolonged economic and wage growth, virtually full employment and strong terms of trade. Yet the decade from 1975 to 1985 saw a slump in economic growth, rising unemployment, declining exports and escalating inflation. ${ }^{118}$

The causes of what came to be known as 'stagflation' (stagnant growth and rapid inflation) are linked to a number of external shocks that were felt around the world in 1973 such the abandonment of the fixed exchange rates of Bretton Woods and the first of the oil shocks. Domestically, New Zealand had enjoyed largely open export access to the British market for its goods since 1840, which became increasingly constrained following the United Kingdom's accession to the European Community in 1973.

The increased focus on the role of inflation in the economy during the decade gave the CPI greater prominence as an economic indicator. At the same time the effective abandonment of the Court of Arbitration's wage setting mechanism in the 1970s in favour of national wage bargaining shifted the primary locus of the conflict between labour and capital over wages and the CPI mechanism from the Court to the negotiating table and central government. ${ }^{119}$ Typically negotiators from both sides of the labour divide in wage negotiations would use the level of the CPI as the starting position while arguing over whether other factors could be added or subtracted from the inflation baseline. ${ }^{120}$

The CPI also underwent significant changes in 1974 by switching from a 'use' to an 'expenditure' method for determining the relative weighting and selection of the 'basket of goods'. The 'use' approach treated the time period used for weighting in which goods or services are used by a household whereas the 'expenditure'

\footnotetext{
${ }^{118}$ Brian Roper and Chris Rudd, 1993, State and Economy in New Zealand. Auckland: Oxford University Press, p. 2

119 Pat Walsh, 1993 'The State and Industrial Relations in New Zealand' in Brian Roper and Chris Rudd, State and Economy in New Zealand. Auckland: Oxford University Press

${ }^{120}$ Brian Easton, 2014, 'A Political Economy of the Consumers Price Index' in Sharleen Forbes, and Antong Victorio (eds), 2014,The New Zealand CPI at 100: History and Interpretation, Wellington: Victoria University Press, p.125
} 
approach treated items as to when they were paid for by the household. This had significant consequence to the treatment of items such as durable goods which would normally be used and paid for over a long time period. At the same time, the bi-annual Household Economic Survey commenced which was used to reweight the index on a regular and more 'scientific' basis. Importantly, for the purposes of this case study, the index now included mortgage interest costs for new houses.

Broadly, the governmental response to the downturn of the 1970s in most developed economies, particularly in the Anglosphere, was the adoption of what came to be known as neo-liberal or 'new Right' economic and social policies. Key tenets of the 'new school' were deregulation of markets, privatisation and corporatisation of government activities and departments along with liberalisation of financial markets including unrestricted capital flows and floating exchange rates. Continuing the long-held tendency of policy-makers to 'copy-and-paste' overseas ideas, such policies were introduced in New Zealand from the mid-1980s, although with far greater haste and ideological veracity than elsewhere.

Following the election of the Labour government in 1984, the Treasury presented its prescription for salvation from the weak economic growth, rising unemployment and high inflation that had plagued New Zealand for the previous ten years. In its briefing to the incoming government, while acknowledging weakening global economic output and the decline in New Zealand exports relative to imports, the Treasury laid most of the blame for poor performance at the macro-economic response of the outgoing Muldoon government. The Treasury's plans included market liberalisation, redesign of the welfare state, 'flexible' labour markets and monetarist disinflationary macroeconomic policies.

\section{3 'INFLATION TARGETING’ AND THE RESERVE BANK ACT}

Over four terms of Labour and National governments from 1984 to 1996 the remodelling of the state and the New Zealand economy as proposed by Treasury took place. One of the key planks of this realignment was the introduction of 'inflation-targeting' monetary policy. In the 1988 Budget, the Minister of Finance, Roger Douglas announced his plan to change monetary policy so that the Reserve Bank of New Zealand (RBNZ) would "implement policies that make the maximum contribution to achieving and maintaining a stable general level of prices." 121

${ }^{121}$ Roger Douglas, 1988 Budget, p.10 
As inflation escalated in the 1970s, without corresponding economic growth to compensate for rapid price change, efforts by economies including New Zealand to control the situation were amplified. The story of state attempts to control inflation was that of a 'search for the holy grail of monetary policy' - a readily applicable rule that exerts control over the value of money. During the primacy of the Bretton Woods system from 1944 to 1971 inflation targeting was not actively contemplated by most governments because of its incompatibility with pegged exchange rates. But the collapse of Bretton Woods left a vacuum for new monetary policies to be proposed and tested.

Inflation targeting was associated with the rise of monetarism, an economic theory that contends that variation in the money supply influences the output of an economy and price levels which is best addressed by controlling the growth of the money supply. This doctrine is commonly associated with Milton Freidman who argued that the supposed trade-off between lower unemployment at the cost of higher inflation was false. Once people in an economy adjusted their behaviour to higher inflation, the economy would return to a so-called 'natural rate of unemployment'. Therefore, while governments could temporarily lower unemployment through higher inflation, once the economy got over the initial 'surprise' and adjusted to the faster rate of price change, employment would ultimately return to where it started from but with the higher inflation still in place. Therefore it was better to not to use monetary policy to address unemployment but to focus on price stability in the medium-to-long term. Governments and policy-makers saw some validation in Friedman's ideas during the 1970s as inflation increased without any corresponding decline in unemployment.

The rise of rational expectations theory in economics during the 1970s was also a key element of inflation targeting monetary policy. In 1977, Finn Kydland and Edward Prescott used game theory to demonstrate why fixed rules are preferable to the discretion of policymakers. ${ }^{122}$ This was further developed by Robert Barro and David Gordon who contended that rules, discretion and reputation are integral to the operation of monetary policy. ${ }^{123} 124$ Extending that framework further, Kenneth Rogoff argued that economies will be better off through the appointment of a central banker who places greater weight on a stable rate of inflation-rate

\footnotetext{
${ }^{122}$ Finn E. Kydland and Edward C. Prescott, 1977, 'Rules Rather than Discretion: The Inconsistency of Optimal Plans', The Journal of Political Economy Vol. 85, No. 3 (June 1977), pp.473-492

${ }^{123}$ Robert Barro and David Gordon, 1983, 'A Positive Theory of Monetary Policy in a Natural Rate Model', The Journal of Political Economy, Vol. 91, No. 4 (August 1983), pp. 589-610

${ }^{124}$ Robert Barro and David Gordon, 1983, 'Rules, discretion and reputation in a model of monetary policy', Journal of Monetary Economics, Vol. 12, No. 1, pp. 101-121
} 
relative to the rate of employment. ${ }^{125}$ Tempering this idea, Susanne Lohmann argued that better outcomes are achieved if the government retains the right to override an independent central banker during extreme economic crises. ${ }^{126}$ Both Rogoff and Lohmann agree on the importance of the government's choice of central banker, arguing that government select central bankers whose preferences and conduct of monetary policy maximise the government's expected utility.

Under the National government of 1975-1984, officials within both Treasury and the RBNZ had been proponents of the new monetarism of Milton Freidman but were largely ignored by Robert Muldoon, who was both Prime Minister and the Minister of Finance. But upon taking office in 1984 Roger Douglas instructed the RBNZ to devise plans to 'Muldoon-proof' monetary policy. ${ }^{127}$ Thus officials within the central bank and Treasury set about devising new monetary policy regimes and operational structures for the bank.

In a 1986 memorandum to Douglas, RBNZ officials proposed that the central bank should have full operational independence as that would provide a "disciplinary check on various other policies, notably fiscal policy". ${ }^{128}$ In a later paper the bank also proposed that by having a single objective of price stability it would be better able to achieve its goal while other state agencies could focus on economic objectives such as full employment. ${ }^{129}$ In briefing papers presented to the re-elected Labour government in 1987, Treasury encouraged Roger Douglas to follow a new monetary policy based on rules, credibility and transparency and to make stable and low inflation its top priority. ${ }^{130}$ The briefing papers provided by the RBNZ simultaneously reinforced the proposals for a singular focus on price stability while devoting a substantial section of the brief to the importance of autonomy for the bank. ${ }^{131}$

To speed up implementation of the reforms, associate Minister of Finance and trained economist Peter Neilson was delegated to find a mutually agreeable position for the Bank and Treasury. After consulting with officials at the United

\footnotetext{
${ }^{125}$ Kenneth Rogoff, 1985, 'The Optimal Degree of Commitment to an Intermediate Monetary Target', Quarterly Journal of Economics, 100, pp. 1169-1189

${ }^{126}$ S. Lohmann, 1992, 'Optimal Commitment in Monetary Policy: Credibility versus Flexibility', American Economic Review. Vol. 82, No. 1, pp. 273-86.

127 John Singleton, 2006, Innovation and Independence: The Reserve Bank of New Zealand 1973-2002, Auckland: Auckland University Press, p. 138

${ }^{128}$ Singleton, Innovation and Independence, p. 143

${ }^{129}$ Singleton, Innovation and Independence, p. 149

130 The Treasury, 1987, 'Economic Management' from Government Management: Brief to the Incoming Government 1987 Volume I., Government Printer: Wellington

${ }^{131}$ Singleton, Innovation and Independence, p. 154
} 
States Federal Reserve Board and the central banks of Canada, Germany and the UK as well as a variety of neo-liberal academics, Neilson came to the conclusion that the RBNZ needed a strong decision-maker with personal credibility who had the integrity to resign if his or her policies were interfered with by government. In early 1988, Neilson informed Douglas that he favoured more precision and clearer quantification of the ultimate inflation target. Neilson also proposed that the target be set by the government which would be codified in a contract signed directly with the Governor rather than the central bank. ${ }^{132}$ Soon after his discussion with Neilson, Douglas publically set inflationary expectations in a television interview where he stated that the aim of his monetary policy would be to reduce CPI inflation to 'around 0 , or 0 to 1 per cent' within two years. ${ }^{133}$ The pledge of Douglas was widely mocked in the media at the time.

The dismissal of Douglas as Finance Minister in late 1988 proved to be no impediment to the implementation of the monetary policy, if anything it sped up the process as it gave new Minister David Caygill the opportunity to demonstrate his commitment to neo-liberal ideas. Outside of government, there was some opposition to the inflation targeting regime, particularly the singular objective of price stability, from union groups, the Manufacturers' Federation, some academics and the National Council of Women. On the other hand, the policy was largely supported by groups such as the Business Round Table, Federated Farmers as well as neo-liberal academics. Because it was presented as a 'scientific truth' as part of a wide-ranging neo-liberal paradigm shift the revolutionary monetary policy received relatively little public attention despite the salience of inflation among the public. There were just 23 submissions received by the Select Committee that deliberated on the details of the legislation. ${ }^{134}$ The insignificant levels of media coverage regarding the new policy belied the significance of the legislation to the management of the New Zealand economy.

While there was some opposition to the changes within the governing Labour Party and the opposition National Party, it was largely muted and in 1989 the Reserve Bank Act was passed unanimously by Parliament. The legislative codification of inflation targeting in the Act states that "The primary function of the Bank is to formulate and implement monetary policy directed to the economic objective of achieving and maintaining stability in the general level of prices." ${ }^{" 135}$ As

\footnotetext{
${ }^{132}$ Singleton, Innovation and Independence, pp. 155-156

${ }^{133}$ Michael Reddell, 1999, 'Origins and early development of the inflation target', Reserve Bank of New Zealand Bulletin, Vol. 62, No 3.

${ }^{134}$ Singleton, Innovation and Independence, p. 158

${ }^{135}$ The Reserve Bank Act 1989, Section 8
} 
the most prominent public measure of 'price stability' the CPI became an essential component of the new inflation targeting regime. The politics that added this new function to the CPI would, in turn, ultimately change its form.

\subsection{THE CPI AND THE 'POLICY TARGET AGREEMENT'}

The design of the monetary regime stipulated that the inflation target would be set by the government in consultation with the RBNZ. This target was contractualised in the form of a 'Policy Target Agreement' (PTA) between the Reserve Bank Governor and the Minister of Finance. The Governor would be personally responsibly if inflation exceeded the target within the short-term of one year. If inflation went outside the range the Governor had to explain to parliament why the breach occurred and face the possibility of dismissal if the breach was egregious. The PTA was designed to make the Governor publicly accountable and give the bank a more corporatist structure in line with the emphasis on 'outputs' that had recently been imposed on the wider public sector. On the other hand, by making a single person responsible for meeting the target could increase the possibility of policy mistakes.

While there were a number of potential options to assess whether the Governor had met the goal of price stability, the CPI was chosen as the contractual target because "it was widely known and was an inflation measure that most people were familiar with." 136 Despite the ubiquity of the CPI, the PTA acknowledged that the index was "not an entirely suitable measure" of price change for the new monetary policy. As Brian Easton notes "it could be argued that the choice of consumer prices in the target agreement neither follows logic or common sense" as private household consumption makes up around $60 \%$ of economic activity of which $40 \%$ is consumption via imports through which, other than the exchange rate, New Zealand has little influence over the cost of. ${ }^{137}$ A statistic that measured inflation in the whole economy, such the GDP deflator or a suite of measures may have been more suitable but for the public awareness of the CPI. In addition, as the CPI was commonly used in wage negotiations, the index set expectations of employers and workers as to the expected level of wage increases which in turn affected the level of 'underlying inflation' the bank aimed to control.

\footnotetext{
${ }^{136}$ The Treasury, 1997, 'Home Ownership in the Consumers Price Index: A paper prepared for the CPI Revision Advisory Committee - Treasury Comments', March 1997. p. 5

${ }^{137}$ Brian Easton, 'A Political Economy of the Consumers Price Index', p.127
} 
Those points aside, the CPI was considered unsuitable as a target by the bank particularly because the index directly included interest rate costs. ${ }^{138}$ According to inflation targeting theory, adjusting monetary policy by increasing interest rates would, in the medium term, tend to lower inflation. But increasing interest costs would - ceteris paribus - increase CPI inflation in the short term, possibly pushing price change outside the boundaries of the agreed target, thus violating the Governor's contract with the Minister. Thus the CPI was enshrined as the inflation target for "practical purposes" but the RBNZ was permitted to devise an alternative index of 'underlying inflation', the Housing Adjusted Price Index (HAPI) which excluded interest rates and purchases of existing houses. ${ }^{139}$ The PTA specified if there was forecast deviation in annual inflation of at least half a percentage point between the CPI and the HAPI, the Governor and the Minister could renegotiate the agreement to "take account of the deficiencies in the construction of the CPI." ${ }^{140}$ Although the HAPI was discontinued in 1992, the bank continued to use alternative 'underlying inflation' measures (such as CPI excluding interest costs), alongside the 'official' CPI measure specified in the PTA until 1997.

\subsection{THE 1997 CPI REVISION ADVISORY GROUP}

This ambiguity between the CPI as a target and the goal of the RBNZ to maintain 'price stability' was ultimately exploited by the Bank, Treasury, the financial sector and central government to change the form of the index. Despite the enshrined political independence of the Government Statistician, he was also legislatively required to produce statistics to meet the needs of its users. The CPI has multiple and occasionally conflicting uses, of which the monetary policy use has greater political and institutional power supporting it than the others, therefore it was only a matter of time until the index was remodelled towards those requirements. The power imbalance between those that used the CPI for indexation relative to those that supported its use in monetary policy was further exacerbated by the introduction of the Employment Contracts Act which increased 'flexibility' in labour relations and weakened the political power of the union movement. This law also cemented the societal shift away from the expectation for employers to pay a 'living wage' based on fairness and the 'cost of living' as under the Court of

\footnotetext{
${ }^{138}$ Reserve Bank of New Zealand, 1990, 'Policy Targets Agreement: March 1990'

139 Ibid.

${ }^{140}$ Ibid.
} 
Arbitration and towards wage increases being "justified by productivity improvements." ${ }^{.141}$

In 1971 the Minister of Statistics set forth a review of the CPI which utilised a Revision Advisory Committee (RAC) of interested parties invited to discuss and make recommendations to the Government Statistician regarding the structure of the index and its suitability for its users. This committee was based on the precedent set from the review of a similar group in 1948, and a principal recommendation of the 1971 committee was that such reviews should be carried out on a regular basis going forward. These reviews ensured that the index was meeting the purposes of its users. Since then reviews of the CPI by the RAC have been carried out in 1978, 1985, 1991, 1997, 2004 and 2013. Generally, the recommendations of the RACs were implemented within 2 years of their reports, although not all recommendations to the Government Statistician were ultimately adopted.

From 1948 until 1997 the committee was chaired by the Government Statistician. The Statistician stood aside from the RAC from 2004 onwards, ostensibly because the purpose of the committee was to give independent recommendations of the users of the index to the Government Statistician to decide upon. As the Statistician was not a user and was rather the arbitrator of the index structure, the chairpersonship was handed over to an 'independent' person so as to ensure the RAC provided independence of the RAC. In 2004 the committee was chaired by retail bank economist John McDermott and in 2013 by the former Retirement Commissioner, Diane Crossan, previously a manager at AMP, a financial services company. These choices of chairperson demonstrate the interest groups that the $\mathrm{CPI}$ is now prioritised to serve.

Although membership of the committee is ultimately determined by the Statistics Department and its Minister, the changing composition of representatives on the RAC also shows how the influential actors in the construction of the index have changed over time. It however must be noted that although the composition of the committee is not the sole source of public and interest group input, public submissions were called for by each RAC, although numbers tended to be very low. As Table 2 shows, from 1971 to 1997 the committee generally comprised a wide cross-section of the users of the index. Until 1991, there were relatively few representatives of government departments and notably the 1971 RAC that

\footnotetext{
${ }^{141}$ The Treasury, 1997, 'Home Ownership in the Consumers Price Index: A paper prepared for the CPI Revision Advisory Committee - Treasury Comments', March 1997. p. 2
} 
recommended the inclusion of mortgage interest in the index was the only committee to not include a Treasury representative. As the CPI has taken on greater importance in the financial sector and in macro-economics the size and scope of the committees has narrowed. The 2004 and 2013 RACs comprised just three interest group representatives alongside a number of persons appointed for their expertise (although that is not to say they were not representing interests in some form). But the modification in the size and scope of the RAC from 2004 onwards can also be linked to the highly contentious report of the 1997 committee.

\section{TABLE 2: CPI REVISION ADVISORY COMMITTEES 1971-2013}

\begin{tabular}{|l|l|l|l|}
\hline \multicolumn{1}{|c|}{1971} & \multicolumn{1}{c|}{1978} & \multicolumn{1}{c|}{1991} \\
\hline $\begin{array}{l}\text { Chair } \\
\text { Sovernment }\end{array}$ & $\begin{array}{l}\text { Chair } \\
\text { Government } \\
\text { Statistician }\end{array}$ & $\begin{array}{l}\text { Chair } \\
\text { Government } \\
\text { Statistician }\end{array}$ & $\begin{array}{l}\text { Chair } \\
\text { Government } \\
\text { Statistician }\end{array}$ \\
\hline Representatives of & Representatives of & Representatives of & Representatives of \\
\hline Statistics Dept. & Treasury & Treasury & Treasury \\
\hline Public Sector Unions & Statistics Dept. & Statistics Dept. & Statistics Dept. \\
\hline Trade Unions & Public Sector Unions & Dept. of Trade & Reserve Bank \\
\hline Women & Trade Unions & Trade Unions & Labour Dept. \\
\hline Retailers & Women & Women & $\begin{array}{l}\text { Social Welfare } \\
\text { Dept. }\end{array}$ \\
\hline Employers & Retailers & Retailers & Commerce Dept. \\
\hline Farmers & Employers & Employers & Trade Unions \\
\hline Consumers & Farmers & Farmers & Women \\
\hline & Consumers & Consumers & Retail Banks \\
\hline Experts & Experts & Experts & Farmers \\
\hline Academic (Statistics) & Academic(Statistics) & Tech. Consultant & Employers \\
\hline Academic(Economics) & & & Manufacturers \\
\hline & & & Consumers \\
\hline & & & Experts \\
\hline & & & Tech. Consultant \\
\hline
\end{tabular}




\begin{tabular}{|c|c|c|}
\hline 1997 & 2004 & 2013 \\
\hline Chair & Chair & Chair \\
\hline Government Statistician & Bank Economist & Public Servant (Finance) \\
\hline Representatives of & Representatives of & Representatives of \\
\hline Treasury & Business & Business \\
\hline Statistics Dept. & Trade Unions & Trade Unions \\
\hline Reserve Bank & Social Services & Reserve Bank \\
\hline Commerce Dept. & Experts & Experts \\
\hline Social Welfare Dept. & Academic (Economics) & Economist (Commercial) \\
\hline Trade Unions & $\begin{array}{l}\text { Academic } \\
\text { (Statistics) }\end{array}$ & $\begin{array}{l}\text { Academic } \\
\text { (Business Management) }\end{array}$ \\
\hline Retailers & Technical Consultant & Technical Consultant \\
\hline Employers & & Academic (Statistics) \\
\hline \multicolumn{3}{|l|}{ Farmers } \\
\hline \multicolumn{3}{|l|}{ Manufacturers } \\
\hline \multicolumn{3}{|l|}{ Retail Banks } \\
\hline \multicolumn{3}{|l|}{ Experts } \\
\hline Technical Consultant & & \\
\hline
\end{tabular}

In 1985, at a time of rapid change in the state sector and the wider New Zealand economy the RAC proposed that there be little change to the CPI as it was "an authoritative, independent, unbiased measure of the level of price inflation as it affects households and that the index is acceptable to its wide range of users."142 In 1991, soon after the index began to be used in the conduct of monetary policy, the committee again declined to "propose any radical alterations" to the structure of the index emphasising "the essential soundness of the present Consumers Price Index." ${ }^{143}$ But there was a significant point of contention among committee members. Appearing for the first time on the committee, the Reserve Bank opposed the continued inclusion of mortgage interest within the CPI regimen but was not supported in its opposition by any of the other representatives. ${ }^{144}$

During the 1990s the Reserve Bank experienced teething problems with the new inflation targeting monetary policy. While the rate of inflation had fallen to historical lows in the early 1990s, there was a continuing issue with deviation between the 'headline' CPI which was the basis of the Policy Targets Agreement and 'underlying' inflation, i.e. the long run trend that excludes transitory price

\footnotetext{
${ }^{142}$ Consumers Price Index Advisory Committee, 1985, Report of the Consumers Price Index Revision Advisory Committee May 1985, Wellington: Government Printer. p.11

${ }^{143}$ Consumers Price Index Advisory Committee, 1991, Report of the Consumers Price Index Revision Advisory Committee 1991, Wellington: Government Printer. p.5

${ }^{144}$ Report of the Consumers Price Index Revision Advisory Committee 1991, p.56
} 
changes, which the bank aimed to control. By 1994 annual headline inflation had increased to $2.8 \%$, well above the $0-2 \%$ target range, although underlying inflation was still within the range. ${ }^{145}$ The bank at that time was producing its own calculation of underlying inflation but it was decided by the bank and Minister to adopt the methodology of Statistics New Zealand for removing interest costs from the CPI which increased the level of underlying inflation. The bank also continued to emphasise its focus on the underlying target even though the contract between the Minister and the Governor was based upon headline CPI inflation. This caused confusion amongst the public and drew allegations of inconsistency against the bank. $^{146147}$

The Governor exceeded the target range on both underlying and headline CPI inflation during 1995 and 1996 which further dented the credibility of Governor Don Brash and the inflation targeting regime. But it was the communication problems between the differing measures that gave renewed vigour to the bank's demands that Statistics New Zealand remove interest costs from the headline index. This was especially important as inflation targeting theory is based on expectations and credibility. If 'rational' economic actors are confused by the signalling of the bank due to multiple measures of inflation how are they to adjust expectations for inflation?

The meetings of the 1997 Revision Advisory Committee were highly contentious. As the committee report states "The variety of views expressed by committee members on the form of the CPI was more diverse than had occurred in any of the previous five reviews; public submissions reflected the same diversity of views." The recommendations that were presented were compromises because "the balance of opinion expressed by committee members did not fall strongly in favour of specific direction with regard to any single measure."149

The bank approached the 1997 RAC proceedings armed with technical arguments and research to justify the removal of interest charges from the index. Treasury, which for reasons unknown supported the maintenance of mortgage interest in the 1991 review, steadfastly argued for its removal in a more overtly political manner. Although the public positions of other committee members are officially unknown, the support of employers, farmers and retail banks were also corralled behind the

\footnotetext{
${ }^{145}$ Singleton, Innovation and Independence, p. 189

${ }^{146}$ Singleton, Innovation and Independence, p. 188

${ }^{147}$ Craig Howie, 1996, 'Bank might use tobacco as inflation smokescreen', The Dominion, March 51996

${ }^{148}$ Statistics New Zealand, 1997, Report of the Consumers Price Index Revision Advisory Committee 1997. Wellington: Statistics New Zealand, p.7. 149 Ibid.
} 
RBNZ and Treasury. On the other side, representatives of trade unions and consumers, and it was rumoured that at one point, the Government Statistician himself, supported mortgage interest rates remaining in the index. ${ }^{150}$

Although the reason for the bank's advocacy of the removal of interest from the index were due to its communication and conduct of monetary policy, the bank claimed it was not approaching the committee with a "narrow perspective" solely focussed on the CPI as a monetary policy tool. ${ }^{151}$ Instead the bank presented its arguments 'scientifically', based around what the CPI 'should' measure. Despite the conflicting objectives between the differing uses of the CPI that necessitated compromise and pragmatism, the bank contended that a "clear conceptual basis" for the index was "an essential starting point, if not the end point, for all of its potential uses." 152

The RBNZ argued that there was no room within its "clear conceptual basis" for mortgage costs stating that "interest rates do not belong in the CPI". The bank argued that interest rates were not consumption and did not fall within the Oxford English Dictionary definition of a service. Rather that interest charges were the cost of bringing consumption forward over time, but were not an act of consumption in itself. The bank also cited a number of other countries that did not include interest charges in their version of the CPI, while acknowledging that other countries did include this item and that other economies had multiple indexes for multiple purposes. A number of international studies and research from bank officials that supported the position were also provided.

Treasury largely echoed the views of the Reserve Bank, although disagreeing with the bank on the inclusion of 'imputed rentals' for owner-occupied housing due to the difficulty of applying that measure to New Zealand's relatively high home ownership rate, although later changing that view to match that of the RBNZ. Unlike the bank, Treasury argued for the importance of removing interest costs for the purposes of monetary policy so as to reduce 'volatility' in the index. Treasury also worked with their Australian counterpart to co-ordinate this change to the CPI which was not coincidentally also proposed in Australia at the same time.

Treasury also argued that over the long-term there would be no difference to the indexation levels provided by the CPI for benefits and wages as lower inflation during times of high interest rates would be evened out by relatively higher

\footnotetext{
${ }^{150}$ Brian Fallow, 1997, 'Reserve Bank backs CPI without interest costs', The New Zealand Herald, November 26 1997.

${ }^{151}$ Reserve Bank of New Zealand, 1997, 'Reserve Bank submission to CPI Advisory Committee: May 1997'

152 Ibid.
} 
inflation during periods of low interest rates. This argument, however, made little allowance for changing life patterns, while the change may be neutral over a decade or longer, a person may only receive a childcare or student allowance for a relatively short period of time at a time of high or low interest costs which are not being adequately compensated for.

\subsection{THE 'INTEREST-FREE’ CPI}

Despite the opposition to the arguments of the Reserve Bank and Treasury, the defenders of the status quo were outnumbered. As the committee report states "the balance of the arguments has shifted in favour of an official measure of consumer price change which excludes the cost of servicing debt." This demonstrates the shift in political power and the political environment since the 1991 committee of which only the Reserve Bank supported the exclusion of interest costs. The committee ultimately agreed, by majority decision, to remove interest costs from the headline CPI (along with other conceptual changes including the shift to an 'acquisitions-based' model for the index which are not the focus of this chapter) to better support monetary policy.

Some members were opposed to this change but the committee was able to reach an understanding on how changes to the treatment of debt service costs would be possible. It was considered practical to exclude such costs from the CPI as long as a range of other measures of price change and purchasing power were also developed. This would ensure that public confidence was maintained in the available measures of the impact of price change on households.

To compensate for the change to the main CPI it was unanimously agreed by the committee that alternative indexes (including an 'outlay-based' that included interest costs and real disposable income indexes) would be developed that could be used for other purposes such as indexation of benefits and wage negotiations. It was agreed that the new 'interest-free' headline CPI would not be introduced until the alternative indexes became available. This did not eventuate. While Statistics New Zealand went ahead with the removal of interest from the index in 1999 in accordance with the majority view of the committee, the alternative indexes that were unanimously agreed to by the RAC were never produced.

One month after the committee recommendations were published, the Reserve Bank Governor and the Treasurer signed a PTA. The agreement, signed December 15 1997, officially replaced the CPI target with the CPIX - CPI excluding interest costs. In the background note to the agreement, it was explained 
that the CPIX target would likely change in 1999 because of the "Government Statistician's intention to drop interest rates from the official CPI in that year."153

Although there was some qualifying language in the background note, this expectation suggested confidence from the RBNZ and the Treasurer that the Government Statistician would implement the committee recommendations even though he was under no obligation to do so. There were no corresponding moves from the Department of Social Welfare or the Department of Labour to prepare for the introduction of the alternative indexes for the purposes of benefit indexation or in wage negotiations.

In an update on the 1997 recommendations provided to the Treasurer and the Minister of Finance by Treasury in September 1998, it is noted that the committee recommended the development of alternative indexes but no progress report is provided. In the same report Treasury contradicts the view of the RAC and Statistics New Zealand by stating that the revised CPI is "more appropriate as a measure of the cost of living." 154 Despite the view of the revision committee that the new alternative measures would be required to be produced prior to the 1999 introduction of the new CPI to "maintain public confidence in the measurement of price changes affecting households" when formally requested in 2001, funding for the measures was jointly rejected by Treasury, Statistics New Zealand (under a new Government Statistician) and the department's 'External Advisory Committee.' ${ }^{155}$

On October 29 1999, Statistics New Zealand published its revised CPI for the September 1999 quarter with interest costs excluded from the basket of goods. One day prior, the Reserve Bank announced a "minor technical change" to its inflation target that replaced the CPIX with the new CPI. Ten years after the introduction of inflation targeting, politics had changed the definition of inflation.

This chapter demonstrates how political change to the function of the CPI and the political environment it operates within ultimately changed its function. In the 1985 the major use of the index was "in wage adjustment, negotiations and as a basis for maintaining the purchasing power of other forms of household income." ${ }^{156}$ By 1997 the role of the CPI had changed because "current economic

\footnotetext{
${ }^{153}$ Reserve Bank of New Zealand, 1997, Policy Targets Agreement: 1997, http://rbnz.govt.nz/monetary policy/policy targets agreement/0055243.html

${ }^{154}$ The Treasury, 'Treasury Report: Changes to the CPI', September 11998

${ }^{155}$ Chris Pike, 2014, 'CPI Frameworks, 1949-2014' in Sharleen Forbes, and Antong Victorio (eds), The New Zealand CPI at 100: History and Interpretation, Wellington: Victoria University Press p.28

${ }^{156}$ Consumers Price Index Advisory Committee, 1985, Report of the Consumers Price Index Revision Advisory Committee May 1985, Wellington: Government Printer. p.11
} 
policy lies in reducing the exposure of the New Zealand economy to inflation and leaving market determined incomes unadjusted in most situations." As of 2013, the principal use of the CPI was not to measure the purchasing power of consumers but "to inform monetary policy setting". ${ }^{157}$ Despite the legislated independence of the Government Statistician to design the form of official statistics, the function to which these numbers were used for were ultimately political decisions made by political actors.

\subsection{INFORMING INSTITUTIONAL CHANGE THEORY}

This episode of change in the institution of the CPI is instructive to the theory of institutional change. As with the prior case study there are two broad theoretical explanations of change that this episode can inform: a path-dependence-critical juncture model and an incremental change-layering model. Both approaches are useful explanations.

The path dependence approach is salient as it can be argued that the original decision to introduce inflation targeting with the CPI integrated into monetary policy locked in a path that led to the eventual change in the index. In addition, the decision to use the CPI in monetary policy was due to the prevalence of public awareness of the index. This can itself be linked back to the choice of the Court of Arbitration to utilise the index in wage determinations which locked the CPI in the public mind as the trusted measure of the 'cost of living'. Therefore any future efforts to control inflation would necessitate reference to the CPI.

The critical juncture in this explanation is the exogenous shock that occurred to the New Zealand economy in the 1970s. The oil shocks, abandonment of Bretton Woods and the accession of the United Kingdom to the European Community ended the 'golden weather' of the post-war economy. This created the antecedent conditions initially resisted (and arguably exacerbated) by the Muldoon government that enabled the rapid introduction of market and state reforms by the fourth Labour government in 1984.

The shortcomings of this theoretical explanation are the defining of 'sudden shock' of the 'stagflation' of the 1970s and the response to it. The shock was arguably not 'sudden' but prolonged and the responses to it were multiple and varied. The 'think big' asset building programme and the price freeze of the Muldoon government, while largely criticised afterwards were policy responses that were directly linked to

\footnotetext{
${ }^{157}$ Statistics New Zealand, 2013, Report of the Consumers Price Index Revision Advisory Committee 2013, Wellington: Statistics New Zealand
} 
antecedent conditions just as the post-1984 neo-liberal response was. That two vastly different policy responses to the 1970s 'shock' does not directly suggest there was path dependence and that the institution of the CPI was changed because of a punctuated equilibrium. On the other hand, many developed economies ultimately chose similar responses following the 1970s crisis, however there were significant differences between economies, with a broadly similar approach of deregulation but divergent implementations. ${ }^{158}$

The path dependence argument around the creation of inflation targeting monetary policy that eventually changed the CPI in to fit the needs of the new regime appears inadequate. While the choice of the CPI as a monetary policy mechanism influenced the structure of the index, the outcome that eventuated was not predestined. Had the proposal for the creation of alternative indexes been followed through, the CPI may have instead been supplanted as the default measure of the 'cost of living' for the purposes of indexation and wage negotiation.

This case study, even more so than the previous, suggests that the path dependence-critical juncture model has limitations that prevent a complete understanding of why and how institutions change over time. Again the incremental model for institutional change appears to be more instructive. In this circumstance the 'layering' approach is the more instructive typology of incremental change. Despite the collapse of the wage determination mechanism of the Court of Arbitration, the CPI was firmly entrenched as an indexation tool to maintain purchasing power and mitigate increases in the 'cost of living' and remains so today. As such 'conversion' of the CPI did not occur.

Layering of the monetary policy mechanism upon the existing intractable existing functions of the CPI occurred that created a new dynamic and empowered actors such as the Reserve Bank, Treasury and the broader financial sector to bring about change to the index. It also altered the perspective of actors such as merchants, exporters and employers towards the index. The intent of using the CPI in monetary policy was not to supplant the existing system, rather the public credibility of the index was used to support the new institution of inflation targeting. Yet this decision, in time, created new ambiguities that were exploited by actors with increased power over the institution that in turn changed the outcomes produced by the index.

\footnotetext{
${ }^{158}$ Shaun Goldfinch, 2006, 'Shared State Experiments: Policy Transfer and Convergence in Australia and New Zealand', The Otemon Journal of Australian Studies, Vol. 32.
} 
The explanation provided by 'layering' demonstrates the worth of the incremental approach in explaining institutional change. Although it is arguable over what time period constitutes 'sudden' compared to 'incremental' change this case study is a strongly exemplifies incremental change. It shows that a changing political environment can create conditions that bring about new interpretations of rules and institutional processes reshaping institutions through the empowerment and disempowerment of political actors. For political reasons, additional functions were layered upon the CPI changing the status and structure of the institution. Although the CPI was not displaced as an indexation tool, the addition of the functional layer of monetary policy remade the form of the institution through political struggle. 


\section{CHAPTER 5 - CONCLUSION}

\subsection{SUMMARY}

This thesis has demonstrated that it is not technology that changes politics, but that politics changes technology. The CPI had its beginnings in what was once an inquiry into the minimum requirements of a 'worthy' working family required to purchase 'necessities' and was transformed by a series of political decisions into a tool that set the price of labour and then into a tool that also set the cost of capital. The case studies detailed showed that technology, much like wider society is just as susceptible to change through political struggle.

Protecting the 'independence' of technology through legislation or technological improvement cannot prevent the influence of politics if technology is used to implement political decisions and actions. This thesis also shows that further development of technology enables politics to change pre-existing technology even further. Technological improvements in the structure of the CPI, in some respects, made it easier to make political changes to the index, especially so after the CPI began to be used in the conduct of monetary policy.

The first case study showed that the CPI was converted through political processes by its attachment to the modification of wages. Putting what was initially devised as a tool of social discovery into the conflict between labour and capital ultimately reshaped the device. The struggle among political forces over time caused change when a consensus among them was reached following World War II that remade the CPI into an 'objective' measure based on average family outgoings rather than that of a 'working-man'.

The second case study demonstrated that through layering an additional function upon the existing purposes of the index, new political forces became involved in the struggle over the index. These forces, broadly representing the financial sector, had greater political strength than their opponents and were able to bring about institutional change that suited their preferences. Despite the legislated political independence given over to the construction of official statistics, change occurred because the supposedly 'apolitical' index was used to perform highly political functions of redistribution.

\subsection{INFORMING THEORETICAL RESEARCH}

This thesis adds to the body of knowledge on historical institutionalism and institutional change. The case studies suggest that the idea of path dependence and 
related theories are underdeveloped and at times inadequate. The examples of change through political struggle in the CPI surrounding the Court of Arbitration and the monetary policy of the Reserve Bank demonstrates the merit of the incremental change theories devised by Thelen. This body of work from which the concepts of layering and conversion have emerged fit the story of political change in the CPI well but more research is needed to refine and further add to this engaging area of political and historical research.

Theoretical areas that require further inquiry are around what constitutes 'significant' change and what is to be considered 'incremental' or 'sudden'. The question of why some political actors that should be influential at bring about political change to institutions are seemingly from the political struggle that brings about change needs further examination. Regarding the second case study, why was the Department of Labour seemingly absent from the political struggle that led to the removal of interest costs from the CPI? Although actors and interests of the labour movement were on the 'losing' side in this struggle over the institution of the CPI, interests such as labour unions were not absent. Why were the Reserve Bank and Treasury, critical actors in regards to the latter study, almost entirely absent from the first case study?

\subsection{AREAS FOR FURTHER EMPIRICAL RESEARCH ON THE CPI}

This thesis raises many areas for further research in the epistemology of the CPI and the broader role of official statistics. As the field of price index research broadens, comparative case studies will need to be undertaken to show the different paths of development that indexes and other statistics take over time. In particular, case studies showing the relative political and technological development of the Australian and New Zealand price indexes will yield valuable insights into why and how these statistics have developed in the way they have. As closely related economies with similar international and domestic political influences and interests, the story of why the indexes of the two states diverged from the 1920s through to the 1970s and then became more closely harmonised in the 1990s should prove to be a fruitful area for further research.

As the CPI has become more technologically sophisticated, 'manipulation' of its indexation mechanism has become easier for political actors. Recently, the New Zealand government legislated for large increases in excise taxes on tobacco. This would have had a flow on effect on the indexation of benefits and other transfer payments linked to the CPI. To avoid the increased expenditure, the Government 
legislated for benefit payments to be linked to the 'CPI excluding tobacco'. 159 'This was possible due to the technological changes made to the CPI in the 1990s that compartmentalised the index.

While this incident was not 'manipulation' or direct interference in the structure of the index as was conducted by Peter Fraser in the 1940s in relation to the inclusion of alcohol, it was arguably a debasement of the intent of 'objective' 'cost of living' increases. The 'CPI excluding tobacco' still includes goods and services such as the price change of overseas travel and luxury items that from one perspective, should not affect 'cost of living' increases for benefit payments. Demonstrating what an overtly political act this decision was, the Government continues to use a version of the CPI that includes tobacco prices for the annual indexation of excise duties including alcohol, tobacco and fuel. During Parliamentary debate on this issue, the opposition Labour Party called for an inquiry into how the CPI is used to index Government payments and receipts. ${ }^{160}$ This is also an area that deserves further academic inquiry.

\subsection{AREAS FOR FURTHER RESEARCH REGARDING OFFICIAL STATISTICS}

The ability of governments to enact policy changes that involve the transfer of billions of dollars over time with very little regard from the public is another area for further inquiry. As Culpepper has noted in his theory of 'Quiet Politics' regarding corporate control of politics, 'noisy politics' surrounds issues that have "high salience" to the electorate, politicians thus adjust their positions to meet voter preferences on these issues. 'Quiet politics' occurs in the context of issues with "low salience", such as the structure and implementation of price indexes to which most voters are largely indifferent. Within the context of "low salience" issues that are important high-level business and elites, it is possible to use this 'information asymmetry' to bring about legislative and regulatory outcomes that elites prefer. ${ }^{161}$ Although Culpepper applies this theory to laws of corporate governance in France, Germany, the Netherlands, and Japan, this theoretical framework has strong applicability to the study of price indexes and official statistics in general.

\footnotetext{
${ }^{159}$ Customs and Excise (Tobacco Products-Budget Measures) Amendment Act 2013

160 Hansard, 2013, Customs and Excise (Tobacco Products-Budget Measures) Amendment Bill; and Bills Therefrom - Third Readings, http://www.parliament.nz/ennz/pb/debates/debates/50HansD $2012101600000028 /$ customs-and-excise-tobaccoproducts $\%$ E2\%80\%94budget-measures-amendment

${ }^{161}$ Culpepper, Pepper D, 2011, Quiet Politics and Business Power: Corporate Control in Europe and Japan. New York: Cambridge University Press.
} 
The story of change in the CPI is also instructive to what change may occur with regards to newer forms of constructed knowledge such as happiness indicators and carbon emission measurements. The story of the CPI shows that the original intent of an institution can be altered significantly over time through politics. As newly developed statistics are applied for political purposes, which interest groups will emerge and engage in political struggle over their structure and application, and what transformations could occur that change them?

Relatedly, what could happen to existing statistics such as measures of the balance of payments if such numbers are placed within critical political areas such as monetary policy? For example, The New Zealand Labour Party recently proposed adding the 'external balance' to the price stability target of the Reserve Bank. ${ }^{162}$ If implemented what effect could that have on the measure of the current account balance, if any?

Further to this, the story of the CPI informs research into the area of official statistics. Is there too much reliance on such numbers in politics and policymaking? Given the increased sophistication of technology in the $21^{\text {st }}$ Century, is it time to reduce the political and social emphasis on aggregate measures of 'unemployment' and 'GDP' that can obscure as much as they enlighten? There is an argument that more bespoke statistics that focus narrowly on specific policy areas could produce better outcomes. Furthermore, there is also an argument that there is already too much focus by policy-makers on numbers, whether narrow or broad in scope and more attention needs to be paid to causes rather than quantification.

\subsection{THE FUTURE OF THE CPI}

That the CPI as an institution changed by political struggle means the index is not insulated from further political change. For example, the recent campaign by interests representing labour agitating for a 'living wage' could, if successful over the medium term, return the CPI towards more closely representing the concept of a 'cost of living' measure rather than a macro-economic statistic that caters for the interests of the financial sector. The recent announcement of Statistics New Zealand that once again, there will be further investigation of alternative indexes to better represent the interests of labour could ultimately dislodge the CPI from its ubiquitous and multi-layered position as a 'catch-all' statistic that serves multiple

\footnotetext{
${ }^{162}$ New Zealand Labour Party, 2014, 'Improving Macroeconomic Stability', https://www.labour.org.nz/sites/default/files/issues/eu-mp-policy.pdf
} 
purposes simultaneously. ${ }^{163}$ But as this thesis has demonstrated, the political context that the index operates within determines which interests and actors wield sufficient political power to control, and if willing, alter the index system to better suit their preferences. Yet in the contemporary political environment, it seems unlikely the index will be reshaped or created anew to better suit the purposes of income adjustment. Instead with new ambiguities being introduced into the CPI system, such as the treatment of tobacco, there may need to be a total reworking of how people keep up with the 'cost of living' that does not involve indexation.

${ }^{163}$ Rob Stock, 2013, 'One-size CPI doesn't fit all', Sunday Star Times, August 18 2013, http://www.stuff.co.nz/business/industries/9059046/One-size-CPI-doesn-t-fit-all 


\section{Bibliography}

1991 Consumers Price Index Advisory Committee. 1991. Purposes and uses of the Consumers Price Index. Wellington: Statistics New Zealand.

Ackrill, Robert, and Adrian Kay. 2006. "Historical-institutionalist perspectives on the development of the EU budget system." Journal of European Public Policy 13(1): 113-133.

Alonso, William, and Paul Starr. 1987. The Politics of numbers. New York: Russell Sage Foundation.

Anderson, Michael. 2003. Review of the New Zealand Consumers Price Index. Wellington: Statistics New Zealand.

Appendices to the Journals of the House of Representatives. 1890. Report of Royal Commission investigation into Sweating. H-5.

Appendices to the Journals of the House of Representatives. 1893. Report of the Department of Labour. H-10.

Appendices to the Journals of the House of Representatives. 1903. Report of the Department of Labour. H-10.

Appendices to the Journals of the House of Representatives. 1924. Report of the Government Statistician. H-22.

Appendices to the Journals of the House of Representatives. 1925. Report of the Government Statistician. H-22.

Appendices to the Journals of the House of Representatives. 1928. Report of the Government Statistician. H-22.

Appendices to the Journals of the House of Representatives. 1929. Report of the Government Statistician. H-22.

Appendices to the Journals of the House of Representatives. 1937. Report of Social Science Research Bureau. H-34.

Appendix to the Journals of the House of Representatives. 1944. Report on The New Zealand Wartime Prices Index. Wellington: Government Printer.

Appendix to the Journals of the House of Representatives. 1948. Report of Index Committee 1948. Wellington: Government Printer. H-48.

Arnold, M.N. 1982. Consumer prices, 1870 to 1919. Wellington: Victoria University of Wellington.

Australian Bureau of Statistics. 1997. Outcome of the 13th Series Australian Consumer Price Index Review. Canberra: Australian Bureau of Statistics. Available at: http://www.abs.gov.au/AUSSTATS/subscriber.nsf/log?openagent\&64530_1997.pdf\&6453.0 \&Publication\&10F150019D15C748CA2571CC000CB34A\&\&Oct\%201997\&12.11.1997\&L atest (Accessed July 7 2011) 
Australian Bureau of Statistics. 2010. Outcome of the 16th Series Australian Consumer Price Index Review. Canberra: Australian Bureau of Statistics. Available at: http://www.abs.gov.au/AUSSTATS/subscriber.nsf/log?openagent\&64690_Dec\%202010.pdf \&6469.0\&Publication\&14BC4357F855B7C0CA2577EE000D7B4B\&\&Dec\%202010\&10.12 .2010\&Latest (Accessed July 72011 )

Banzhaf, H. Spencer. 2001. "Quantifying the Qualitative: Quality-Adjusted Price Indexes in the United States, 1915-61.” History of Political Economy 33(Supplement): 345-370.

Banzhaf, H. Spencer. 2004. "The Form and Function of Price Indexes: A Historical Accounting." History of Political Economy 36(4): 589-616.

Barnes, G.S. 1913. 'Letter from Department of Labour, British Board of Trade to Government Statistician, Malcolm Fraser, 25 April 1913.' in STATS Series 1, Record 22/1/5, Archives NZ.

Barro, Robert and David Gordon. 1983a. "A Positive Theory of Monetary Policy in a Natural Rate Model”, The Journal of Political Economy, 91(4), (August 1983): 589-610

Barro, Robert and David Gordon (1983b) "Rules, discretion and reputation in a model of monetary policy", Journal of Monetary Economics, 12 (1): 101-121

Baumgartner, Frank and Bryan D. Jones. 1993. Agendas and Instability in American Politics. Chicago: University of Chicago Press.

Beaud, Jean-Pierre and Jean-Guy Prévost. 2005. 'Statistics as the Science of Government: The Stillborn British Empire Statistical Bureau, 1918-20'. The Journal of Imperial and Commonwealth History, 33(3) September 2005: 371-372.

Béland, Daniel. 2007. "Ideas and Institutional Change in Social Security: Conversion, Layering, and Policy Drift*." Social Science Quarterly 88(1): 20-38.

Bernhard, William, J. Lawrence Broz, and William Roberts Clark. 2002. "The Political Economy of Monetary Institutions.” International Organization 56(04): 693-723.

Berumen, Edmundo, and Victor A. Beker. 2011. "Recent developments in price and related statistics in Argentina." Statistical Journal of the IAOS 27: 7-11.

Blyth, Mark. 2002. Great transformations: economic ideas and institutional change in the twentieth century. Cambridge, UK: Cambridge University Press.

Boskin, Michael J, and Dale W Jorgenson. 1997. "Implications of Overstating Inflation for Indexing Government Programs and Understanding Economic Progress." American Economic Review 87(2): 89-93.

Boskin, Michael J., Ellen R. Dulberger, Robert J. Gordon, Zvi Griliches, et al. 1998. "Consumer Prices, the Consumer Price Index, and the Cost of Living." The Journal of Economic Perspectives 12(1): 3-26.

Brash, Donald T. 1999. "New Zealand's Remarkable Reforms.” In Fifth Annual IEA Hayek Memorial Lecture, London.

British Parliamentary Papers. 1889. "Returns of Expenditure by Working Men.” 1889, C.5861. 
British Empire Statistical Conference. 1920. Report and Resolutions adopted by the First Conference of Government Officers engaged in dealing with Statistics in the British Empire (with four appendices). London: H.M. Stationery Office.

Campbell, John L. 2004. Institutional change and globalization. Princeton, New Jersey: Princeton University Press.

Christopher, A.J. 2008. 'The quest for a census of the British Empire c.1840 - 1940', Journal of Historical Geography. Vol. 34: 280

Cohen, I. Bernard. 2006. The Triumph of Numbers: How Counting Shaped Modern Life. New York: W.W. Norton \& Company, Inc.

Collier, David and Ruth Berins Collier. 1991. Shaping the Political Arena: Critical Junctures, the Labor Movement, and Regime Dynamics in Latin America. Princeton: Princeton University Press.

Collins, J.W. 1912. Inquiry into the Cost of Living in New Zealand. Wellington: Government Printer

Comodromos, George, and Justine Ferrer. 2011. "Incremental Institutional Change and Australian Universities." International Review of Business Research Papers 7(1): 330-339.

Consumers Price Index Advisory Committee. 1971. Report of the Consumers Price Index Revision Advisory Committee. Wellington: Government Printer.

Consumers Price Index Advisory Committee. 1978. Report of the Consumers Price Index Revision Advisory Committee May 1985. Wellington: Government Printer.

Consumers Price Index Advisory Committee. 1985. Report of the Consumers Price Index Revision Advisory Committee May 1985. Wellington: Government Printer.

Consumers Price Index Advisory Committee. 1991. Report of the Consumers Price Index Revision Advisory Committee 1991. Wellington: Government Printer.

Cook, Len W. 1989. “A Sample of Highlights in the History of Government Statistics." The New Zealand Statistician 24(2): 57-65.

Cook, Len, and Rodney Lewington. 1997. What should the Consumers Price Index measure? Wellington: Statistics New Zealand.

Cope, Jeff, Rosemary Goodyear, and Anne McAllister. 2009. "Measuring economic progress? How Statistics New Zealand has measured the economy since 1945." In Wellington: Statistics New Zealand. Available at: http://www.nzae.org.nz/conferences/2009/pdfs/Measuring_economic_progress_How_Statist ics_New_Zealand_has_measured the economy_since_1945.pdf (Accessed June 14 2011)

Cullen, Michael J. 1975. The statistical movement in early Victorian Britain: the foundations of empirical social research. Hassocks, Sussex: Harvester Press.

Culpepper, Pepper D. 2005. "Institutional Change in Contemporary Capitalism: Coordinated Financial Systems since 1990.” World Politics 57(2): 173-199. 
Culpepper, Pepper D. 2011. Quiet Politics and Business Power: Corporate Control in Europe and Japan. New York: Cambridge University Press.

Van Daele, Jasmien. 2005. "Engineering Social Peace: Networks, Ideas, and the Founding of the International Labour Organization.” International Review of Social History 50(3): 435-466.

Deeming, Christopher. 2010. "The Historical Development of Family Budget Standards in Britain, from the 17th Century to the Present." Social Policy \& Administration 44(7): 765-788.

Diewert, W. Erwin, and Alice O. Nakamura. 1993. Essays in Index Number Theory Volume 1. Elsevier Science Publishers.

DiMaggio, Paul. 1998. "The New Institutionalisms : Avenues of Collaboration.” Journal of Institutional and Theoretical Economics (JITE) / Zeitschrift für die gesamte Staatswissenschaft 154(4): 696-705.

Easton, Brian. 1997. The Commercialisation of New Zealand. Auckland: Auckland University Press.

Eberstadt, Nicholas. 1995. The Tyranny of Numbers: Mismeasurement and Misrule. Washington, D.C.: The AEI Press.

Endres, A. M. and K. E. Jackson. "Policy responses to the crisis: Australasia in the 1930s." In Capitalism in Crisis: International Responses to the Great Depression, ed. W.R. Garside. London: Pinter Publishers, p. 148-165.

Ewing, Ian, Yuong Ha, and Brendan Mai. 2004. What should the Consumers Price Index measure? Wellington: Statistics New Zealand.

Fallow, Brian. 1997. "Reserve Bank backs CPI without interest costs." The New Zealand Herald, November 261997.

Firth, Raymond. 1959. Economics of the New Zealand Maori. Wellington: Government Printer.

Fisher, Irving. 1912. "An International Commission on the Cost of Living." The American Economic Review 2(1): 92-101.

Forbes, Sharleen and Antong Victorio. 2014. The New Zealand CPI at 100: History and Interpretation. Wellington: Victoria University Press

Franklin, Harvey. 1981. "The Flight of the Kiwi: Economic Growth and Society in New Zealand." International Journal 36(4): 898-915.

Fraser, Malcolm. 1914a. "Report of the Government Statistician on Visit to Statistical Offices of the Commonwealth of Australia and Australian States", Appendices to the Journals of the House of Representatives, 1914. H-12.

Fraser, Malcolm. 1914b. "Letter from Government Statistician to Victorian State Statistician, A.M. Laughton.” 24 July 1914, in STATS Series 1, Record 22/1/7, Archives NZ.

Fraser, Malcolm. 1915a. Report on the Cost of Living in New Zealand 1891-1914. Wellington: Government Printer. 
Fraser, Malcolm. 1915b. Letter from Government Statistician to Commonwealth Statistician, George Knibbs, 24 June 1915, in STATS Series 1, Record 22/1/7, Archives NZ

Fraser, Malcolm. 1920. Prices: An Inquiry into Prices in New Zealand. 1891-1919. Wellington: Government Printer.

Fraser, Malcolm. 1920. "Report of Government Statistician on British Empire Statistical Conference." Appendices to the Journals of the House of Representatives, 1920. H-12.

Fraser, Malcolm. 1923. "Letter from Government Statistician to Professor of Economics, Canterbury College, Albert Tocker, 30 May 1923." in STATS Series 1, Record 22/1/32, Archives NZ.

Goldfinch, Shaun. 2000. Remaking New Zealand and Australian Economic Policy. Wellington: Victoria University Press.

Goldfinch, Shaun. 2006. "Shared State Experiments: Policy Transfer and Convergence in Australia and New Zealand." The Otemon Journal of Australian Studies. Vol. 32.

Gordon, Robert J. 1981. "The Consumer Price Index: Measuring Inflation and Causing It." The Public Interest 63(Spring 1981): 112-134.

Gordon, Russel. 1997. Background to the Household Economic Survey. Wellington: Statistics New Zealand. Available at: http://www2.stats.govt.nz/domino/external/web/aboutsnz.nsf/e8c536ed07c05396cc256b1400 009cb0/4437960103aacb904c2567ff007a74b9/\$FILE/hes.doc (Accessed June 6 2011)

Gourevitch, Peter Alexis, and James Shinn. 2007. Political power and corporate control: the new global politics of corporate governance. Princeton, New Jersey: Princeton University Press.

Gregory, Robert. 2009. "Public Policy: Saying One Thing While Doing Another." Political Science 61(2): 63-73.

Griffiths, Daniel. 2009. "Core Inflation Measures Produced in New Zealand.” In Neuchâtel, Switzerland: Statistics New Zealand. Available at:

http://www.ottawagroup.org/Ottawa/ottawagroup.nsf/4a256353001af3ed4b2562bb00121564/ 1bd88ae9af79cfa1ca257693001bb7fa/\$FILE/2009\%2011th\%20meeting\%20\%20Danie1\%20Griffiths\%20\%28Statistics\%20New\%20Zealand\%29_Core\%20inflation\%20 measures\%20produced\%20in\%20New\%20Zealand.pdf (Accessed July 7 2011)

Ha, Yuong, and Peter Mohan. 2004. Progress on the 1997 Revision Advisory Committee Recommendations. Wellington: Statistics New Zealand. Available at: http://www.stats.govt.nz/ /media/Statistics/Publications/Developments/2004\%20CPI\%20Re vision\%20Advisory\%20Committee/progress-on-1997-revision-advisory-committeerecommendations.ashx (Accessed May 2 2011)

Ha, Yuong, and Sela Xie. 2004. Measurement limitations in the Consumers Price Index. Wellington: Statistics New Zealand. Available at: http://www.stats.govt.nz/ /media/Statistics/Publications/Developments/2004\%20CPI\%20Re vision\%20Advisory\%20Committee/measurement-limitations-cpi.ashx (Accessed July 7 2011)

Hall, Peter A. and Rosemary C R Taylor. 1996. "Political Science and the Three New Institutionalisms." Political Studies 44(5): 936-957. 
Hansard (New Zealand Parliamentary Debates). 1910. 'Census and Statistics Act: First Reading, November 21 1910'. vol. 153

Haworth, Nigel and Steve Hughes. 2009. "A Distant Detachment: New Zealand and the ILO 1919-1945." Paper presented at 90 years of the ILO: the significance for Australia and New Zealand. Auckland, November 2009.

Hayes, Matthew. 2011. “The Social History of Quantifying Inflation.” Journal of Economic Issues 45(1): 97-111.

Heaton, H. 1921. "The Basic Wage Principle in Australian Wages Regulation.” The Economic Journal, 31(123): 315.

Van Der Heijden, Jeroen. 2010. "A short history of studying incremental institutional change: Does Explaining Institutional Change provide any new explanations?" Regulation \& Governance 4(2): 230-243.

Van der Heijden, Jeroen. 2011. "Institutional Layering: A Review of the Use of the Concept." Politics 31(1): 9-18.

Howie, Craig. 1996. "Bank might use tobacco as inflation smokescreen." The Dominion. March 5 1996.

Hughes, Steve, and Nigel Haworth. 2009. "A Distant Detachment: New Zealand and the ILO 1919-1945." In 90 years of the ILO: the significance for Australia and New Zealand, Auckland.

ILO Bureau of Statistics. 2008. "ILO statistical standards: 85 years of setting international guidelines for labour statistics.” Bulletin of Labour Statistics (1): IX-XXIV.

International Labour Office. 2003a. Consumer Price Indices, 17th International Conference of Labour Statisticians. Geneva: International Labour Organization. Available at: http://www.ilo.org/wcmsp5/groups/public/@dgreports/@integration/@stat/documents/meetin gdocument/wcms_087591.pdf (Accessed May 7 2011)

International Labour Office. 2003b. General Report, 17th International Conference of Labour Statisticians. Geneva: International Labour Organization. Available at: http://www.ilo.org/wcmsp5/groups/public/@dgreports/@integration/@stat/documents/meetin gdocument/wcms_087585.pdf (Accessed May 7 2011)

International Labour Office. 1925. The Second International Conference of Labour Statisticians. Geneva: International Labour Organisation. Available at: http://www.ilo.org/public/libdoc/ilo/ILO-SR/ILO-SR_N8_engl.pdf (Accessed May 7 2011)

International Labour Office. 1947. The Sixth International Conference of Labour Statisticians. Montreal: International Labour Organisation. Available at: http://www.ilo.org/public/libdoc/ilo/ILO-SR/ILO-SR_NS7_engl_part.4.pdf (Accessed May 7 2011)

International Labour Office. 1948. The Sixth International Conference of Labour Statisticians: Montreal, 4 to 12 August 1947, Studies and Reports New Series No. 7 (part 4). Geneva: International Labour Organisation. 
International Labour Office. 1957. The Ninth International Conference of Labour Statisticians. Geneva: International Labour Organisation. Available at:

http://www.ilo.org/public/libdoc/ilo/1957/57B09_95_engl.pdf (Accessed May 7 2011)

International Labour Office. 1962. The Tenth International Conference of Labour Statisticians.

Geneva: International Labour Organisation. Available at:

www.ilo.org/public/libdoc/ilo/1962/62B09_134_engl.pdf (Accessed May 7 2011)

International Labour Office. 1987. The 14th International Conference of Labour Statisticians.

Geneva: International Labour Organisation. Available at:

http://www.ilo.org/public/libdoc/ilo/1988/88B09_74_engl.pdf (Accessed May 7 2011)

International Labour Office et al. 2004. Consumer Price Index Manual: Theory and Practice. International Monetary Fund.

International Labour Organisation. 1944. "Constitution of the International Labour Organisation." New York: ILO.

Jones, S. R.H. 1999. "Government Policy and Industry Structure in New Zealand, 1900-1970." Australian Economic History Review 39(3): 191-212.

Karabell, Zachary. 2013. The Leading Indicators: A Short History of the Numbers That Rule Our World. New York: Simon \& Schuster.

Katznelson, Ira, and Barry Weingast. 2007. Preferences and Situations: Points of Intersection Between Historical and Rational Choice Institutionalism. New York: Russell Sage Foundation.

Keynes, John M. 1912. 'Review: The Course of Prices in New Zealand and Report of Commission on Cost of Living in New Zealand, together with Minutes of Proceedings and Evidence', The Economic Journal. 22(88): 595-598

Kingston, Christopher, and Gonzalo Caballero. 2009. "Comparing theories of institutional change." Journal of Institutional Economics 5(02): 151-180.

Kirshner, Jonathan. 2001. "The Political Economy of Low Inflation.” Journal of Economic Surveys 15(1): 41-70.

Krsinich, Frances. 1999. "Early Official Statistics in New Zealand: Statistics New Zealand up to 1960." In A history of statistics in New Zealand, ed. HS Roberts. Wellington: New Zealand Statistical Association.

Kydland, Finn E. and Edward C. Prescott. 1977. "Rules Rather than Discretion: The Inconsistency of Optimal Plans", The Journal of Political Economy. 85(3), (June 1977): 473-492

Lepore, Jill. 2014. “The Disruption Machine.” The New Yorker. June 232014. http://www.newyorker.com/magazine/2014/06/23/the-disruption-machine (Accessed August 8 2014)

Lohmann, S. 1992. "Optimal Commitment in Monetary Policy: Credibility versus Flexibility." American Economic Review. 82 (1): 273-86. 
Loretto, Roberta. 1997a. Calculation and Structure of the Consumers Price Index. Wellington: Statistics New Zealand. Available at:

http://www2.stats.govt.nz/domino/external/web/aboutsnz.nsf/e8c536ed07c05396cc256b1400 009cb0/4437960103aacb904c2567ff007a74b9/\$FILE/calstruc.doc (Accessed May 17 2011)

Loretto, Roberta. 1997b. How the Consumers Price Index fits into the Statistical System.

Wellington: Statistics New Zealand. Available at:

http://www2.stats.govt.nz/domino/external/web/aboutsnz.nsf/e8c536ed07c05396cc256b1400 009cb0/4437960103aacb904c2567ff007a74b9/\$FILE/system.doc (Accessed May 22 2011)

Mahoney, James and Kathleen Thelen. 2009. Explaining Institutional Change: Ambiguity, Agency, and Power. Cambridge: Cambridge University Press

Mai, Brendan. 2004a. A Review of the Consumers Price Index Classification System. Wellington: Statistics New Zealand. Available at:

http://www.stats.govt.nz/ /media/Statistics/Publications/Developments/2004\%20CPI\%20Re vision\%20Advisory\%20Committee/review-of-cpi-classification-system.ashx (Accessed May 22 2011)

Mai, Brendan. 2004b. Seasonal Adjustment in the Consumers Price Index. Wellington: Statistics New Zealand. Available at: http://www.stats.govt.nz/ /media/Statistics/Publications/Developments/2004\%20CPI\%20Re vision\%20Advisory\%20Committee/seasonal-adjustment-cpi.ashx (Accessed June 7 2011)

Martin, John E. 2010. Honouring the Contract. Wellington: Victoria University Press.

National Development Council. 1969. Report of the Technical Committee on Statistics to the National Development Council. Wellington: Government Printer.

Neale, E.P. 1955. Guide to New Zealand official statistics. 3rd ed. Christchurch: Whitcomb and Tombs.

New Zealand Monetary and Economic Council. 1977. Inflation. Wellington: Government Printer.

New Zealand Monetary and Economic Council. 1971. Inflation and the labour market.

Wellington: Government Printer.

New Zealand Official Yearbook. 1908. Wellington: Government Printer.

New Zealand Truth. 1912. "Cost of Living Commission. The Value of the recent report. Some Conclusions not justified. The disastrous policy of Freetrade." September 71912.

Office of the Minister of Statistics. 2011. 'Statistics 2020: Achieving the Statistical System of the Future.' Budget Cabinet Paper June 2011. http://www.treasury.govt.nz/downloads/pdfs/b112020979.pdf (Accessed May 21 2012)

Otago Witness. 1894. “The Financial Depression and the Theory of Value.” 26 July 1894.

Persons, Warren. 1913. "Review: Report of Commission on Cost of Living in New Zealand, together with Minutes of Proceedings and Evidence." The American Economic Review, 3(1): 143-144

Pierson, Paul. 2000. "Increasing Returns, Path Dependence, and the Study of Politics." The American Political Science Review. 94(2) (June 2000): 251-267 
Plant, Raymond. 2010. The neo-liberal state. New York: Oxford University Press.

Polanyi, Karl. 1957. The great transformation. Boston, MA: Beacon Press.

Porter, Theodore M. 1995. Trust in Numbers: The Pursuit of Objectivity in Science and Public Life. Princeton, New Jersey: Princeton University Press.

Preston, David A. 2009. "Putting Credit Back into Monetary Policy: Reconstructing the New Zealand Monetary Policy Framework.” In Wellington.

Rae, David. 1993. Are retailers normal? The distribution of consumer price changes in New Zealand. Wellington: Reserve Bank of New Zealand.

Redmond, William H. 2003. "Innovation, Diffusion, and Institutional Change.” Journal of Economic Issues 37(3): 665-679.

Reddell, Michael. 1999. "Origins and early development of the inflation target." Reserve Bank of New Zealand Bulletin. 62 (3).

Research New Zealand. 2014. Use and Trust in Official Statistics Survey: 2013. http://www.stats.govt.nz/ /media/Statistics/about-us/corporate-publications/use-trust-ossurvey/use-trust-os-survey-2013.pdf (Accessed July 18 2014).

Reserve Bank of New Zealand. 1990. Policy Targets Agreement: March 1990. http://rbnz.govt.nz/monetary_policy/policy_targets_agreement/0073109.html (Accessed August 2 2014).

Reserve Bank of New Zealand, 1997a, "Reserve Bank submission to CPI Advisory Committee: May 1997."

Reserve Bank of New Zealand. 1997b. Policy Targets Agreement: 1997. http://rbnz.govt.nz/monetary_policy/policy_targets_agreement/0055243.html (Accessed August 2 2014).

Reserve Bank of New Zealand. 2012. "Current Policy Targets Agreement”, September 2012, http://rbnz.govt.nz/monetary_policy/policy_targets_agreement/4944826.pdf (Accessed August 2 2014).

Rodgers, Gerry, Eddy Lee, Lee Swepston, and Jasmien Van Daele. 2009. The ILO and the quest for social justice, 1919-2009. Geneva: International Labour Office.

Roger, Scott. 1995. Measures of underlying inflation in New Zealand, 1981 - 95. Wellington: Reserve Bank of New Zealand.

Rogoff, Kenneth. 1985. "The Optimal Degree of Commitment to an Intermediate Monetary Target." Quarterly Journal of Economics. 100: 1169-1189.

Roper, Brian and Chris Rudd (eds). 1993. State and Economy in New Zealand. Auckland: Oxford University Press.

Rudd, Chris and Brian Roper (eds). 1997. The Political Economy of New Zealand. Auckland: Oxford University Press.

Ruggie, John. 1982. "International regimes, transactions, and change: embedded liberalism in the postwar economic order.” International Organization, Vol. 36: 379-415. 
Russell, George. 1912. "Letter from Minister of Internal Affairs to Minister of Labour, George Laurenson.” 1 July 1912 in STATS Series 1, Record 22/1/7, Archives NZ.

Saunders, Peter. 2006. "The historical development of budget standards for Australian working families.” Journal of Industrial Relations 48(2): 155-173.

Singleton, John. 2006. Innovation and Independence: The Reserve Bank of New Zealand 19732002. Auckland: Auckland University Press.

Skocpol, Theda. 1995. Protecting soldiers and mothers: the political origins of social policy in the United States. Cambridge, MA: Harvard University Press.

Skowronek, Stephen. 1995. "Order and Change.” Polity 28(1): 91-96.

Smyth, David J., and Alan E Woodfield. 1993. "Inflation, unemployment and macroeconomic policy in New Zealand: A public choice analysis." Public Choice 75(2): 119-138.

Stapleford, Thomas A. 2009a. "Aftershocks from a Revolution: Ordinal Utility and Cost-of-Living Indexes." Journal of the History of Economic Thought (Forthcoming).

Stapleford, Thomas A. 2009b. The Cost of Living in America. New York: Cambridge University Press.

Stapleford, Thomas A. 2003. “'The Most Important Single Statistic' : The Consumer Price Index and American Political Economy, 1880-1955."

Statistics New Zealand. 1997. Report of the Consumers Price Index Revision Advisory Committee 1997. Wellington: Statistics New Zealand. Available at:

http://www2.stats.govt.nz/domino/external/web/aboutsnz.nsf/e8c536ed07c05396cc256b1400 009cb0/4437960103aacb904c2567ff007a74b9/\$FILE/ATT9P7ZX/cpirev97g28a.pdf

(Accessed May 22 2011)

Statistics New Zealand. 2006. Consumers Price Index Review: September 2006. Wellington:

Statistics New Zealand. Available at:

http://www2.stats.govt.nz/domino/external/pasfull/pasfull.nsf/4c2567ef00247c6a4c2567be00 08d2f8/4c2567ef00247c6acc257203001390a4?OpenDocument (Accessed May 22 2011)

Statistics New Zealand. 2008. Consumers Price Index, 2008 Review. Wellington: Statistics New Zealand. Available at: http://www.stats.govt.nz/ /media/Statistics/Publications/Prices/cpi2008-review-report.ashx (Accessed May 22 2011)

Statistics New Zealand. 2004. Report of the Consumers Price Index Revision Advisory Committee 2004. Wellington: Statistics New Zealand. Available at:

http://www.stats.govt.nz/ /media/Statistics/Publications/Developments/2004\%20CPI\%20Re vision\%20Advisory\%20Committee/report-cpi-revision-advisory-committee-2004.ashx (Accessed May 22 2011)

Statistics New Zealand. 2013. Report of the Consumers Price Index Revision Advisory Committee 2013. Wellington: Statistics New Zealand. Available at: http://www.stats.govt.nz/browse_for_stats/economic_indicators/CPI_inflation/2013-cpireview-advisory-committee.aspx (Accessed June 20 2014)

Statistics Office. 1949. Monthly Abstract of Statistics, November 30 1949. Wellington:

Government Printer. 
Steinmo, Sven, and Kathleen Ann Thelen. 1992. Structuring politics: historical institutionalism in comparative analysis. Cambridge, UK: Cambridge University Press.

Stock, Rob. 2013. “One-size CPI doesn't fit all”, Sunday Star Times, August 18 2013, http://www.stuff.co.nz/business/industries/9059046/One-size-CPI-doesn-t-fit-all (Accessed July 18 2014).

Stott, Helen. 1997. "Financial services (credit services) in the New Zealand CPI." In Voorburg: Statistics New Zealand. Available at: http://www.ottawagroup.org/Ottawa/ottawagroup.nsf/home/Meeting+3/\$file/1997\%203rd\%2 0Meeting\%20-\%20Stott\%20Helen\%20\%20Financial\%20services $\% 20$ (credit\%20services)\%20in\%20the $\% 20 \mathrm{New} \% 20 \mathrm{Zealand} \% 20 \mathrm{C}$ PI.pdf (Accessed May 22 2011)

Stott, Helen. 1998. "The CPI purpose and definition - the Australasian Debate." In Washington, D.C.: Statistics New Zealand. Available at: http://www.ottawagroup.org/Ottawa/ottawagroup.nsf/home/Meeting\%204/\$file/1998\%204th $\% 20$ Meeting\%20$\% 20$ Stott $\% 20$ Helen, \%20The\%20CPI\%20purpose\%20and\%20definition\%20\%20the\%20Australasian\%20Debate.pdf (Accessed May 22 2011)

Streeck, Wolfgang, and Kathleen Ann Thelen. 2005. Beyond continuity: institutional change in advanced political economies. New York: Oxford University Press.

Thelen, Kathleen Ann. 2004. How institutions evolve: the political economy of skills in Germany, Britain, the United States, and Japan. Cambridge, UK: Cambridge University Press.

The Treasury. 1984. "Part Two Policy Organisational Issues" from Economic Management: Brief to the Incoming Government 1984, Government Printer: Wellington.

http://www.treasury.govt.nz/publications/briefings/1984i/ (Accessed June 3 2012)

The Treasury. 1987. "Economic Management" from Government Management: Brief to the Incoming Government 1987 Volume I., Government Printer: Wellington. http://www.treasury.govt.nz/publications/briefings/1987i/ (Accessed June 3 2012)

The Treasury, 1997, "Home Ownership in the Consumers Price Index: A paper prepared for the CPI Revision Advisory Committee - Treasury Comments”, March 1997.

The Treasury, “Treasury Report: Changes to the CPI”, September 11998

The Wanganui Herald. 1908. "Labour and the Arbitration Act: Address by the Hon. Dr. Finlay." May 23 1908. pp. 5-6

Triplett, Jack E. 2001. "Should the Cost-of-Living Index Provide the Conceptual Framework for a Consumer Price Index?” The Economic Journal 111(472): F311-F334.

United Nations et al. 2009. Practical Guide to Producing Consumer Price Indices. Geneva: United Nations.

Voss, T. R. 2001. 'Institutions' in N. J. Smelser (ed.). International Encyclopedia of the Social \& Behavioral Sciences. Amsterdam: Elsevier Science. pp.7561-7566.

Ward, Michael. 2004. Quantifying the World: UN ideas and statistics. Bloomington, Indiana: Indiana University Press. 
Wells, Graeme, and Keith Fraser. 1986. The tax switch and the CPI : An occasional paper. Wellington: Victoria University Press for the Institute of Policy Studies.

Wong, Jason. 1993. A disaggregated model of the New Zealand consumer price index. Wellington: Reserve Bank of New Zealand.

Wood, George. 1947. "Letter from Government Statistician to Minister in charge of Census and Statistics, 18 July 1947." in STATS Series 1, Record 22/1/71, Archives NZ.

Wood, George. 1976. Progress in official statistics, 1840-1957 : a personal history. Ẅellington: Department of Statistics.

Woods, Noel. 1974. The Industrial Relations Act, 1973 : A study of the legislation. Wellington: Victoria University of Wellington.

Woods, Noel S. 1963. Industrial conciliation and arbitration in New Zealand. Wellington: Government Printer. 